\title{
31. OUTER MARGIN DEPOSITIONAL SYSTEMS NEAR THE CHILE MARGIN TRIPLE JUNCTION'
}

\author{
Kari Strand, ${ }^{2}$ Kathleen Marsaglia, ${ }^{3}$ Randy Forsythe, ${ }^{4}$ Victor Kurnosov, ${ }^{5}$ and Hernán Vergara ${ }^{6}$
}

\begin{abstract}
Ocean Drilling Program Leg 141 drilling recovered an extensive suite of Pliocene to Pleistocene forearc basin deposits within the Chile margin near latitude $46^{\circ} \mathrm{S}$, in the vicinity of the Chile spreading ridge-trench collision. The outer margin setting is dominated by terrigenous siliciclastic sediment input from the Andean volcanic arc, Paleozoic to Mesozoic crustal sources, and the forearc, in slightly varying proportions. The overall controls on sedimentation are complex; of major importance are fluctuations in glaciation, sea-level changes, volcanism, and tectonism (i.e., thrust faulting and uplift due to subduction accretion or subsidence due to subduction erosion).

The sediments encountered are predominantly structureless muds, massive to graded sand, sandstones, and some gravels and conglomerates that were deposited from slope failures, turbidity currents, and suspension processes associated with hemipelagic fallout in basin plain/trench to stacked slope apron environments. During the late Pliocene to Pleistocene, fluctuations of the ice sheet also influenced the outer margin sedimentation; during the glacial maxima in the Pliocene and early Pleistocene, larger quantities of terrigenous sediment were transported to the trench slope by turbidity currents and related gravity flows. Tectonically induced accretion led to overall shallowing-up successions and the formation of small slope basins with a slight coarsening-upward general character in the upper portions of proximal sites. Onshore, uplifted and eroded Paleozoic metasedimentary rocks and deeper crustal complexes shed sediments of dissected arc provenance into the forearc region. Forearc sediment composition indicates a waning of the arc volcanism during the Pliocene-Pleistocene and an emplacement of subaqueous near-trench volcanism during Pliocene along the Taitao Fracture Zone, owing to the progressive spreading-ridge subduction along the Chile margin. Basinal tectonism occurred in the form of ridge-subduction-related subsidence and associated tectonic erosion. The hydrothermal alteration of part of the Chilean accretionary wedge sediments was most likely created by high heat flow from the subducted spreading ridge.
\end{abstract}

\section{INTRODUCTION}

Leg 141 of the Ocean Drilling Program (ODP) drilled five sites in the forearc of the Chile Trench near the Chile margin Triple Junction to investigate the geologic and tectonic processes involved in the subduction of a mid-ocean ridge. The three plates that define the Chile Triple Junction are the Nazca, Antarctic, and South American. The Chile Rise spreading ridge first collided with the Chile Trench about $14 \mathrm{Ma}$ ago (Cande and Leslie, 1986) and since then, the Triple Junction has migrated northward along the margin. The Triple Junction reached the Golfo de Penas about $6 \mathrm{Ma}$. The main focus of the drilling was to prove the effects of spreading-ridge subduction, which was assumed to produce rapid uplift and subsidence of the arc and forearc, a cessation of arc magmatism, anomalous near-trench and forearc magmatism and localized subsidence and extensional deformation of the forearc in the region of the collision (Marshak and Karig, 1977; DeLong et al., 1978, 1979; Cande and Leslie, 1986; Forsythe et al., 1986; Cande et al., 1987). In addition, many convergent margins may have undergone the removal of forearc material from the overriding plate through processes of subduction erosion (Cande and Leslie, 1986; Honza et al., 1989; von Huene and Lallemand, 1990). The situation is complicated by the fact that trench-slope sequences thousands of meters thick at convergent margins undergo continual tectonism in many cases, which molds the configuration of the drainage basins and the sediment dispersal and depositional processes within the sedimentary basin.

\footnotetext{
${ }^{1}$ Lewis, S.D., Behrmann, J.H.. Musgrave, R.J., and Cande, S.C. (Eds.), 1995. Proc $O D P$, Sci. Results, 141: College Station, TX (Ocean Drilling Program).

${ }^{2}$ Department of Geology, University of Oulu, Linnanmaa, FIN-90570 Oulu, Finland.

${ }^{3}$ Department of Geological Sciences, University of Texas at El Paso, El Paso, TX 79968, U.S.A.

${ }^{4}$ Department of Geography and Earth Sciences, University of North Carolina/ Charlotte, Charlotte, NC 28223, U.S.A.

${ }^{5}$ Geological Institute, Academy of Sciences, Pyzhevsky per., 7, Moscow 109017. Russia.

${ }^{6}$ Departamento de Oceanografía, Servicio Hidrográfico y Oceanografico de la Armada, Casilla 324, Valparaiso, Chile.
}

This paper provides a modern example of trench-slope sedimentation near the ridge-trench collision site, giving information that will be of use in recognizing ancient examples. For this purpose, the sedimentary sources, processes, and depositional environments near the Chile margin Triple Junction were related to the sedimentary signatures of subduction accretion or possible subduction erosion and to ascertain the tectonic history of the convergent margin near the ridge collision site.

\section{MATERIALS AND METHODS}

Trends in changes of sedimentary structures, bed-thicknesses, and grain-size were used to trace sediment distribution, a vertical character of sediment sequences, and depositional environments. In some cores, deformation of the structures as a result of coring disturbance and tectonism (i.e., shearing or in-situ brecciation) makes it difficult to distinguish any sedimentary facies, but in many others preservation is good enough to permit sedimentary facies distinction. Thin sections were prepared from several stratigraphic cycles (coarse clastic portions) and petrographically analyzed for texture and grain-size. Fifteen unconsolidated, sand-rich samples were split by wet sieving into a fine fraction $(<0.063 \mathrm{~mm})$, and coarse fraction $(>0.063 \mathrm{~mm})$, weighed, and the coarse fraction dry-sieved into sand subfractions in order to obtain data on grain-size distribution. These data were compared and combined with environmental interpretations, sand detrital modes for 107 samples (Marsaglia et al., this volume), mineralogical analyses (Kurnosov et al., this volume), and quantitative grain-size analyses of nearly 600 predominantly fine-grained samples performed using a laser particle counter or rapid sediment analyzer (RSA) (Diemer and Forsythe, this volume).

\section{REGIONAL AND GEOLOGIC SETTING}

Sites 859,860 , and 861 were drilled as part of a northern transect from the base of the trench slope across the middle and upper slope of the Chile margin about $40 \mathrm{~km}$ north of the Chile Triple Junction near latitude $46^{\circ} \mathrm{S}$ (Figs. 1 and 2). Site 863 was drilled at the base of the 


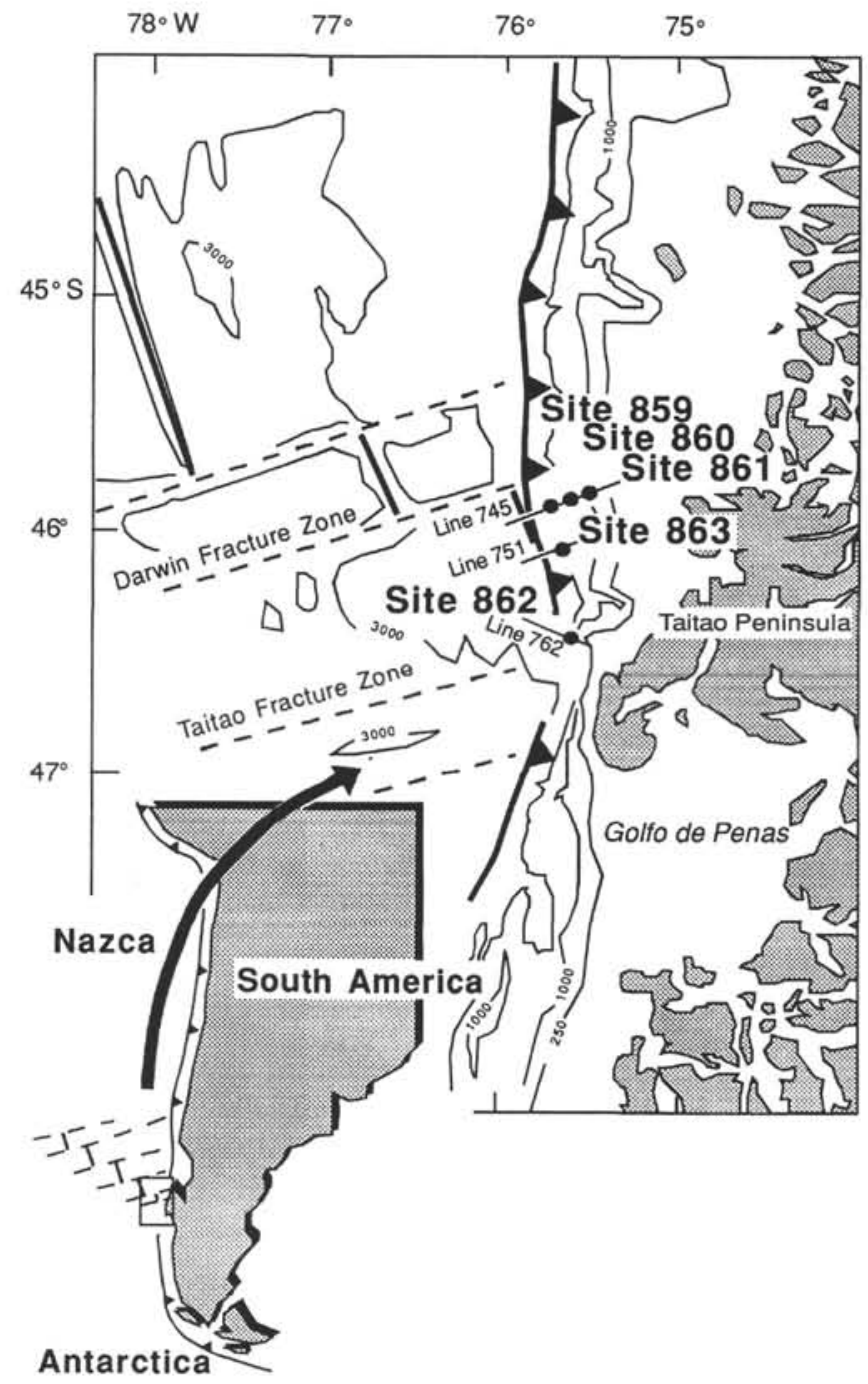

Figure 1. Map showing the main bathymetric and tectonic features of the Chile margin in the vicinity of the Chile Triple Junction, the location of seismic Lines 745,751 , and 762, and Sites 859 to 863 . Bathymetric contours are in meters. Heavy barbed line denotes subduction zone, heavy plain line denotes ridge segment, and light dashed line indicates fracture zones.

trench slope over the subducted rift axis in a position approximately on strike with Site 859 (Figs. 1 and 2). Site 862 is located near the crest of a bathymetric high, the Taitao Ridge (Fig. 2), approximately $25 \mathrm{~km}$ south of the present location of the Chile margin Triple Junction above the trace of the Taitao Fracture Zone (Fig. 1). The ages of the forearcbasin strata and the deformed accretionary wedge drilled during Leg 141 (Fig. 3) range from Quaternary to early Pliocene (Behrmann, Lewis, Musgrave, et al., 1992). The northern transect provides a lithologic characterization of the outer margin at a stage prior to ridge collision, whereas ridge collision occurred approximately $50 \mathrm{ka}$ ago at Site 863 (Bangs et al., 1992). Bangs et al. (1992) propose that Line 745 (Fig. 1) is located where the ridge is expected to collide with the lower trench slope in about 100 k.y. The Taitao Ridge may represent a fragment of oceanic ridge segment in the process of emplacement into the Chile margin or an incipient rift propagated into the forearc over the site of ridge collision (Forsythe and Prior, 1992).

According to the present day offshore bathymetry along the Chile margin (Thornburg et al., 1990), major submarine canyons (e.g., Chacao Canyon and Calle-Calle Canyon) and late Pleistocene trench fans are situated north of the transect, whereas the only large canyon that probably contributed sediments to the Leg 141 sites is located

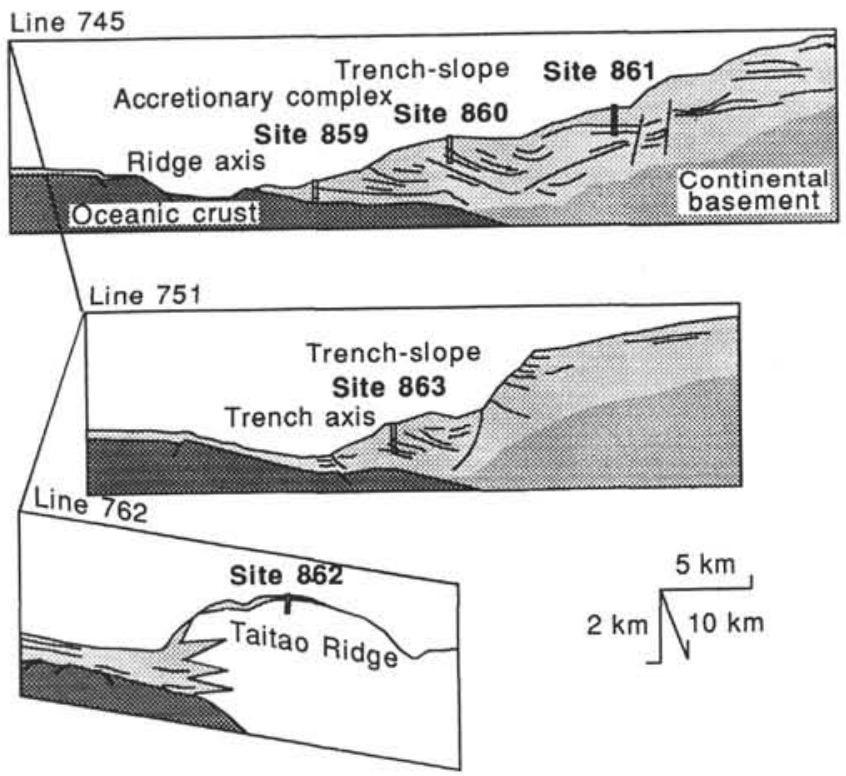

Figure 2. Schematic cross sections constructed for the outer Chile margin along seismic Lines 745, 751, and 762, after Behrmann, Lewis, Musgrave, et al. (1992).

about $20 \mathrm{~km}$ southeast of the Triple Junction (Fig.1). One major submarine channel, the Mornington Channel, runs along the trench axis south of the Triple Junction and is probably fed by sediments derived from the Taitao Peninsula (Cande and Leslie, 1986).

\section{SEDIMENTARY CHARACTERISTICS AND DEPOSITIONAL SYSTEMS}

Eight sedimentary facies have been distinguished in Leg 141 cores based on grain size, texture, and dominant sedimentary structures. The principal clastic sedimentary facies types of Leg 141 deposits and their interpretation are outlined in Table 1. For the sake of brevity, we use the facies names of the unconsolidated sediments, even though some deposits may be lithified. The major outer margin depositional systems are analyzed in terms of these facies types and their vertical distribution and the sedimentary processes are deduced rather than the nature or distribution of morphological features such as canyons.

\section{Northern Transect (Sites 859, 860, and 861)}

\section{Description}

The uppermost part of Site 859 (Fig. 4; Unit I, 0-10 mbsf) consists mainly of laminated to mottled clayey silt and silty clays (Facies 5 and 8 ) and contains abundant microfossils of late Pleistocene age (Shipboard Scientific Party, 1992a). Predominantly upper Pliocene clayey silts and silty clays with low microfossil content make up Subunit IIA (Figs. 4 and $5 ; 10-235$ mbsf). Subunit IIB extends to a depth of 476 mbsf and consists of upper Pliocene silty claystones and clayey siltstones associated with some degree of tectonic thickening (Shipboard Scientific Party, 1992a). The dominant sedimentary facies in Unit II are Facies 5,6, and 8, with sporadic interbeds of Facies 4 in the upper part. Thin, very fine sand-silt couplets (Facies 4 ) show sharp bases and normal grading. Site 859 is, overall, deficient in sand-sized material and the mean grain size, as measured by the laser particle counter, ranges rather uniformly between $8.7 \mathrm{phi}$ and $9.3 \mathrm{phi}$ (Diemer and Forsythe, this volume). The maximum grain-size curves in Figures 4 and 5 show a slightly coarsening trend for Subunit IIA and a wider overall range than in Subunit IIB, with two slightly fining-upward cycles ending in Cores 141-859B-26R and 14R. The maximum grain size indicates the relative amounts of energy required in transport processes. 
Table 1. Summary of facies types used for Leg 141 sediment samples.

\begin{tabular}{|c|c|c|}
\hline Facies & Characteristics & Interpretation \\
\hline 1: Disorganized sandy-silty-clay (diamictite) & $\begin{array}{l}\text { Granule- to pebble-sized clasts dispersed in fine-grained matrix: } \\
\text { inversely to normally graded: bed thickness } 0.8-1.5 \mathrm{~m}\end{array}$ & $\begin{array}{l}\text { Debris flow or high-density fine-grained } \\
\text { turbidity current }{ }^{\mathrm{a}}\end{array}$ \\
\hline 2: Gravel & Matrix-supported to clast-supported gravel or conglomerate & Debris flow ${ }^{a}$ \\
\hline 3: Graded to massive sand & Thin beds of poorly sorted sand or sandstone & $\begin{array}{l}\text { High-density turbidity current or grain } \\
\text { flow }^{\text {a }}\end{array}$ \\
\hline 4: Graded sand-silt couplet & $\begin{array}{l}\text { Couplet composed of a basal sandy unit and massive to laminated fine- } \\
\text { grained sediment }\end{array}$ & Low-density turbidity current ${ }^{\mathrm{a}}$ \\
\hline 5: Laminated to layered silty clay to clayey silt & $\begin{array}{l}\text { Fine-grained sediment showing layering and thin silt-rich horizontal } \\
\text { laminae }\end{array}$ & $\begin{array}{l}\text { Fine-grained turbidity current or traction } \\
\text { transport by bottom-current } t^{\text {a, b.c.d }}\end{array}$ \\
\hline 6: Laminated to massive clay to silty clay & Fine-grained sediment showing fine laminae or structureless & Mud turbidity current ${ }^{\text {3. d.e }}$ \\
\hline 7: Deformed clay to silty clay & Fine-grained sediment showing soft sediment folds, wispy laminae & Mudflow or slump $p^{\text {a. e }}$ \\
\hline 8: Mottled silty clay to clayey silt & $\begin{array}{l}\text { Fine-grained sediments with various proportions of siliceous and } \\
\text { calcareous microfossils; locally bioturbated }\end{array}$ & Hemipelagic sedimentation ${ }^{4}$ \\
\hline
\end{tabular}

Note: ${ }^{\mathrm{a}}=$ Pickering et al., 1986. 1989; ${ }^{\mathrm{b}}=$ Stow and Lovell. 1979; ${ }^{\mathrm{c}}=$ Stow and Shanmugam. 1980; ${ }^{\mathrm{d}}=$ Piper and Stow. $1991:{ }^{\mathrm{c}}=$ Einsele. 1991.

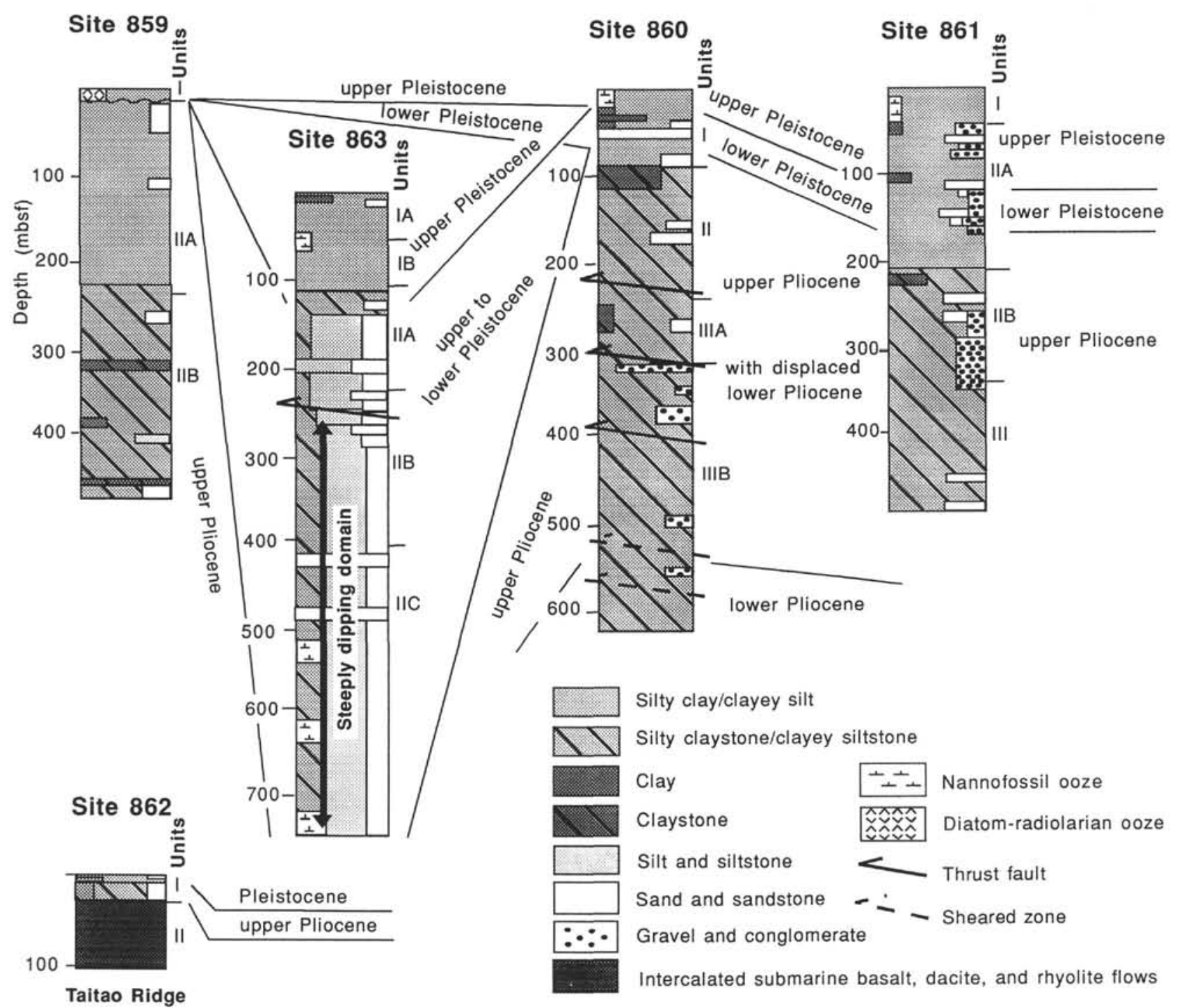

Figure 3. Graphic lithologies and stratigraphic correlation for Leg 141 sites. 


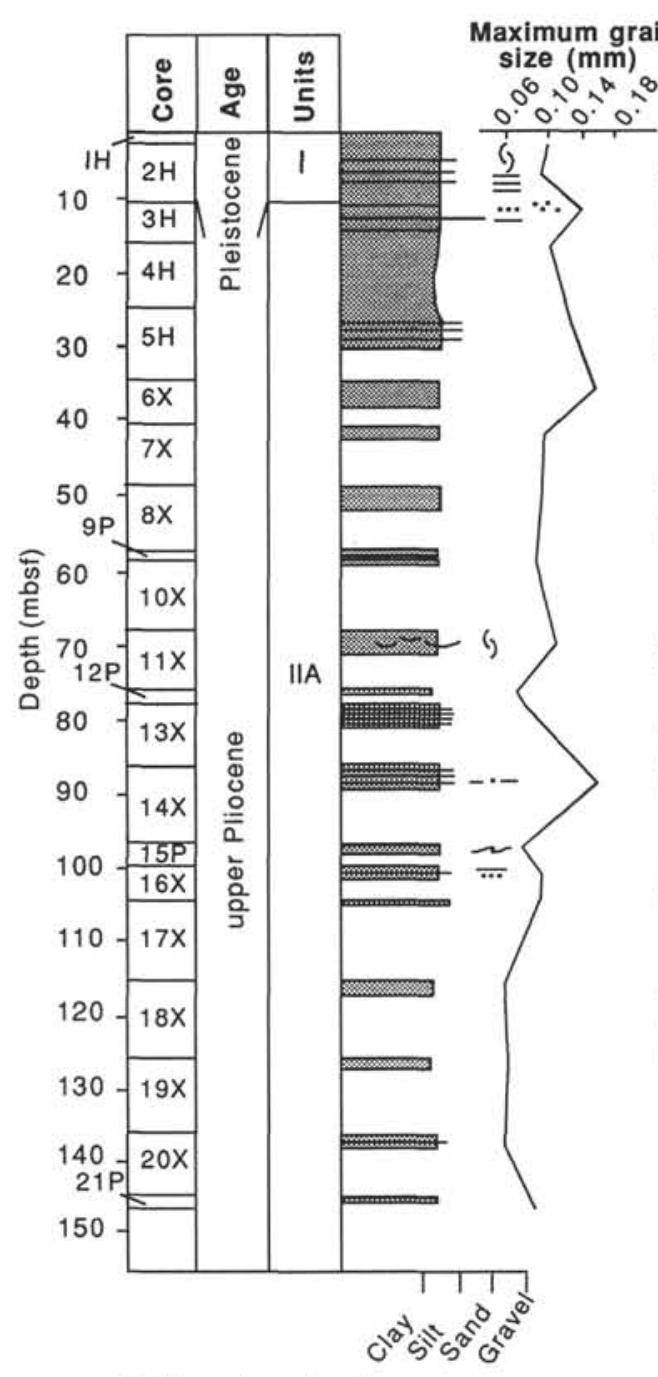

\section{Lithofacies} silt and silty clay with some with prained turbidites
Description

Mottled silty clay to clayey

silt (facies 5 and 8)

Massive to normally

graded sand (facies 3 )

Thin interbeds of silt and silty sand (facies 4 and 5 )

Silty clay to clayey silt with low microfossil content (facies 6)

Concentrations of silty sand

Thinly interbedded clayey isolated pebbles (facies 5) material

Interpretation

Lower trench-slope cover

High-density turbidites

Low-density

fine-grained turbidites

Mud turbidites

Inverse graded clayey silt interbeds (facies 5)

Sediment reworked by bottom currents

\section{Depositional system}

Depositional lobe of slope apron associated with hemipelagic

deposits

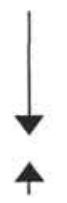

Distal depositional lobe of slope apron

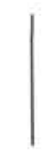

Structureless silty clay to clayey silt disturbed by drilling

Sedimentary structures

\begin{tabular}{|c|c|c|c|c|c|c|c|}
\hline$\because$ & Massive & 矦 & Laminated & $\sim \sim$ & Cross-laminated & $<$ & Thrust fault \\
\hline & $\begin{array}{l}\text { Soft sediment } \\
\text { deformation }\end{array}$ & 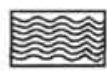 & Wavy bedding & $\cdots$ & Graded bedding (normal) & $1--$ & Sheared zone \\
\hline & Bioturbation & 攵 & $\begin{array}{l}\text { Low-angle } \\
\text { lamination }\end{array}$ & $\cdots$ & Graded bedding (inverse) & 个1 & Distribution of \\
\hline & Dropstones & 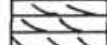 & Cross-bedded & $\sim$ & Scoured contact & & system \\
\hline
\end{tabular}

Lithology
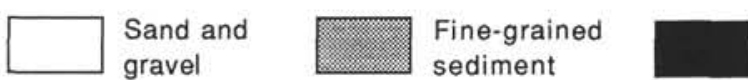

Ash

Figure 4. Stratigraphy, sedimentology, and interpretation of the sequence cored at Hole 859A. The maximum grain-size curve shows values obtained by averaging the diameter of the five largest grains on the smear slides. See Table 1 for an explanation of the facies types.

Site 860 is divided into three lithological units (Fig. 6). Unit I consists of $87.7 \mathrm{~m}$ of clayey silt to silty clay with nannofossils (Facies 8) ranging in age from late Pliocene to Pleistocene and some graded fine-grained sand and silt interbeds (Facies 3 and 4; Fig. 7A). Unit I shows a slight coarsening-upward overall character, and sand beds are more abundant in the upper portions. Unit II ( $87.7-242.5 \mathrm{mbsf})$ is early Pliocene to late Pliocene, with facies that include laminated to massive claystone to silty claystone (Facies 6 and 7), some thin interbeds of laminated silty sandstone, and granule-sized conglomerate (Facies 2). The fine-grained sediment in the middle part of Unit II also contains a small percentage of calcareous recrystallized microfossils. Subunit IIIA (242.5-309.8 mbsf) consists of early to late Pliocene age clayey siltstones (Facies 5), silty claystones with nannofossils (Facies 8), disorganized sandy to silty claystones with dispersed subangular to subrounded pebble- to granule-sized lithic clasts (diamictite) with a sharp base and gradational tops (Facies 1; Fig. 7B), and thin intraformational conglomerate beds (Facies 2). Subunit IIIB occurs between $309.8 \mathrm{mbsf}$ and the bottom of the hole at $617.8 \mathrm{mbsf}$, with lithologies similar to those of Subunit IIIA structurally repeated in three intervals and bracketed by thrust faults or sheared zones (Shipboard Scientific 


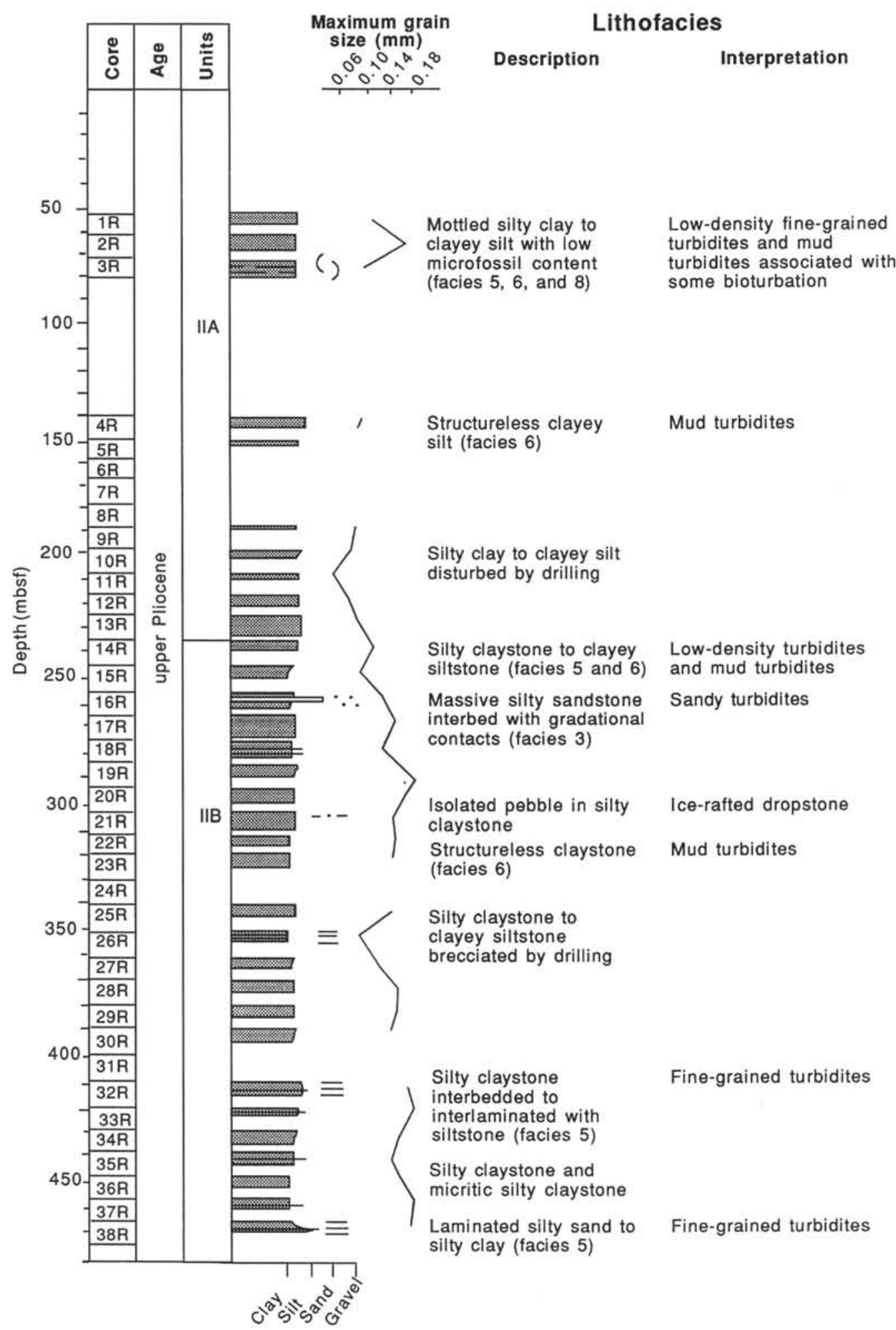

\section{Depositional system}

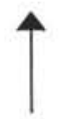

Distal depositional lobe of slope apron associated with hemipelagic deposits

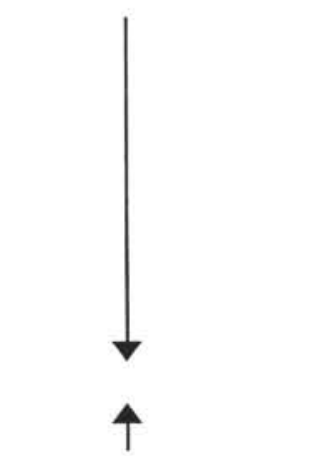

Distal depositional lobe of slope apron

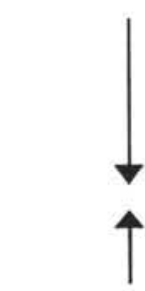

Basin plain/trench fill

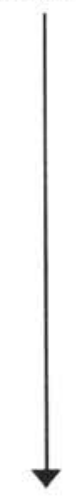

Figure 5. Stratigraphy, sedimentology, and interpretation of the sequence cored at Hole 859B. See Table 1 for an explanation of the facies types. Key and maximum grain-size curve as for Figure 4.

Party, 1992b). The detailed section in Figure 8 illustrates two internal and relatively similar intervals of disorganized sandy silty claystones (Facies 1) followed by silty claystone to laminated siltstone (Facies 5 and 6) and mottled zones of nannofossil chalk (Facies 8) between an inferred sheared zone and a thrust fault. The maximum clast diameter in Facies 1 is generally $1.5-2 \mathrm{~cm}$ and the clasts include pebble-sized siltstones, calcareous sandstone and siltstones, dark volcanic lithic fragments, some greenish shale, and shell and wood fragments. The mean grain size for the fine-grained sediments at Site 860 ranges between 8.2 and 9.1 phi and cyclic downhole changes in grain size correspond fairly well with the above-mentioned structurally repeated intervals, especially at depths of $350-410 \mathrm{mbsf}$ and $520-540 \mathrm{mbsf}$ 


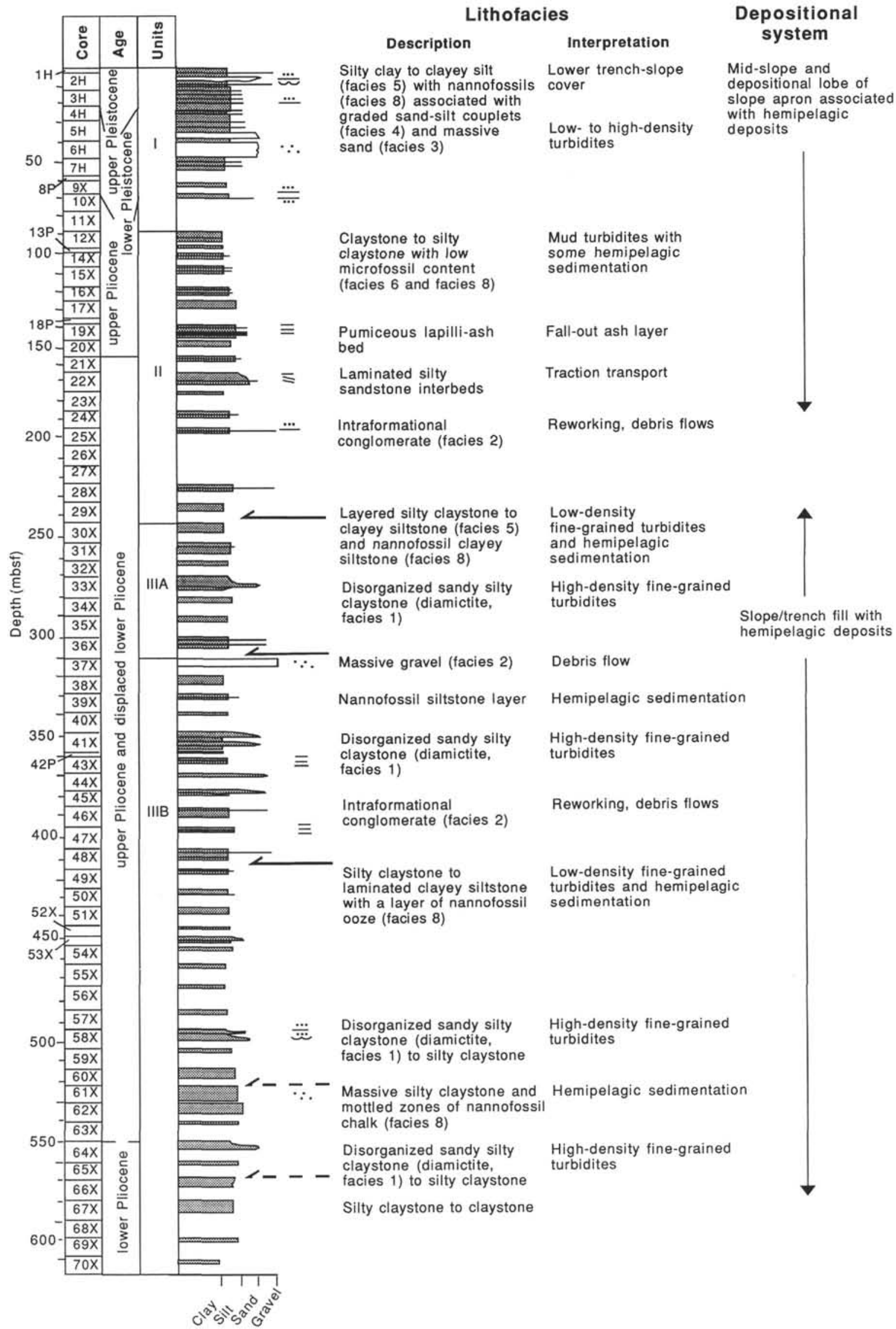

Figure 6. Stratigraphy, sedimentology, and interpretation of the sequence cored at Hole 860B. See Table 1 for an explanation of the facies types. Key as for Figure 4. 
B

$\mathrm{cm}$

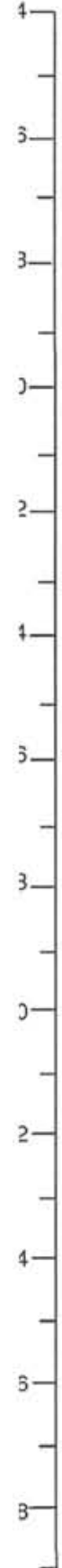

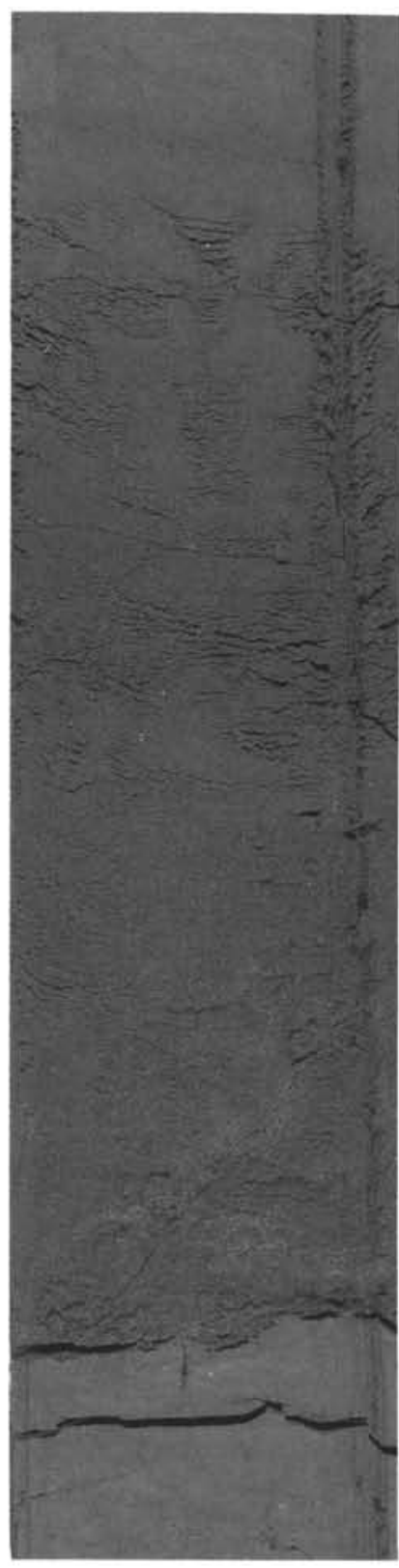

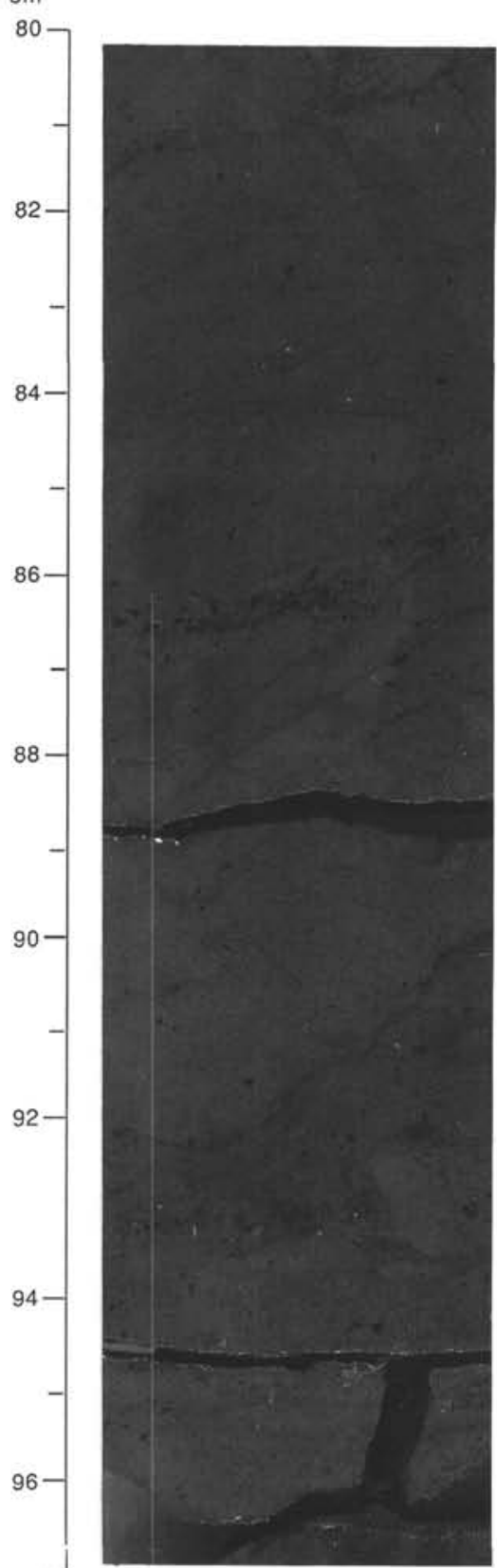

\section{C}

cm

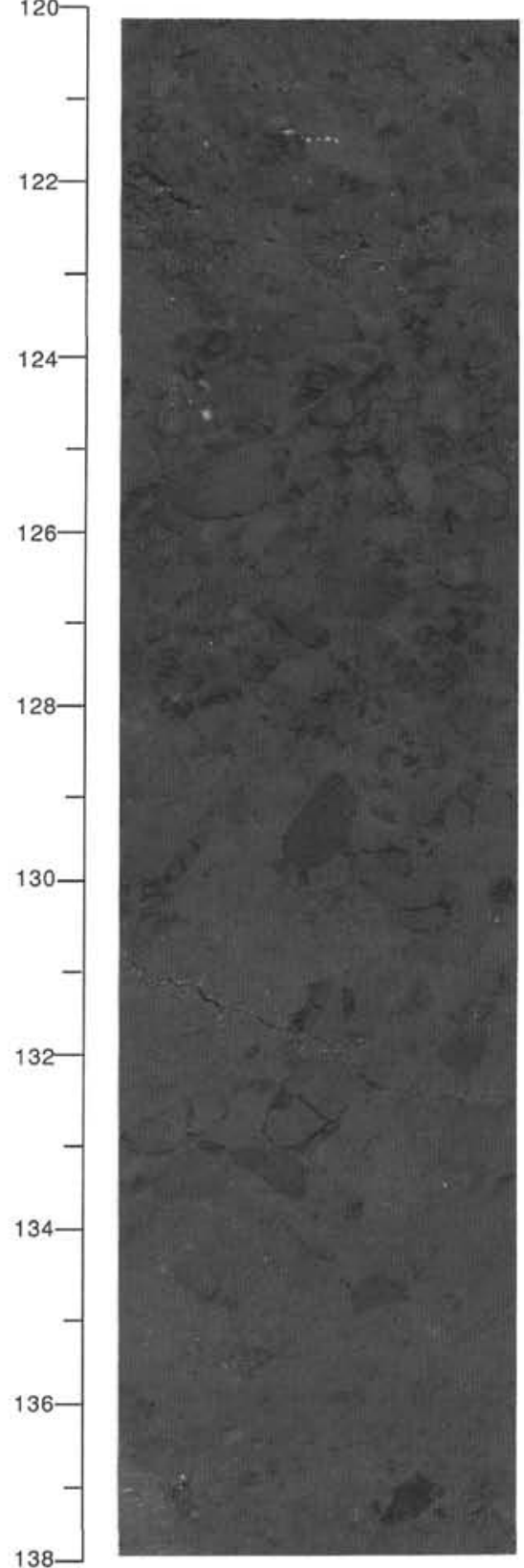

Figure 7. Typical coarse-grained facies types from Sites 860 and 861 . See Table 1 for an explanation of the facies types. A. Graded medium-grained sand-massive silt couplet with sharp basal contact (Facies 4) in Unit I. Sample 141-860B-2H-5, 104-129 cm. B. Disorganized sandy silty claystone with dispersed pebble to granule-sized clasts in Subunit IIIB, showing inverse to normal grading in the basal part of a succession $80 \mathrm{~cm}$ thick and fining upward (Facies 1). Sample 141-860B-58X-1, 80-97 cm. C. Matrix-supported to clast-supported gravel (Facies 2) near the base of a single flow unit in Subunit IIA. Sample 141-861C-10H-3, $120-138 \mathrm{~cm}$.

(Diemer and Forsythe, this volume). The overall decrease in the degree of sorting downhole has a oscillating pattern and a correspondence is observed between coarser and less well-sorted material (Diemer and Forsythe, this volume).

Three lithological units were identified at Site 861 (Fig. 9; Shipboard Scientific Party, 1992c). Unit I (0-43.8 mbsf) consists of Quaternary silty clays and clayey silts containing some nannofossils (Facies 8). Subunit IIA (43.8-208.9 mbsf) contains silty clays and clayey silts of late Pliocene and Pleistocene age with thin intercalations of graded silt, sand (Facies 3 and 4), and matrix- to clast-supported gravelly layers (Facies 2; Fig. 7C). The gravel units vary in thickness from a few centimeters to more than $1 \mathrm{~m}$, with sharp bases and mostly gradational tops, whereas mud-rich gravels may also exhibit sharp upper contacts. In some sequences, gravelly or sandy basal portions grade upward into laminated to cross-laminated clayey silt and then bioturbated silty clay. The gravels are composed of angular to well-rounded clasts of claystone to siltstone, with some wood/plant and shell fragments. Subunit IIB (208.9-351.9 mbsf) has similar, but more lithified lithologies. Unit III (351.9-496.3 mbsf) consists predominantly of silty claystone to clayey siltstone. Sediments drilled at Site 861 are generally sand-poor, with no significant sandy intervals recovered below $350 \mathrm{mbsf}$. The mean grain size ranges between 8.2 and 9.1 phi, featuring some oscil- 


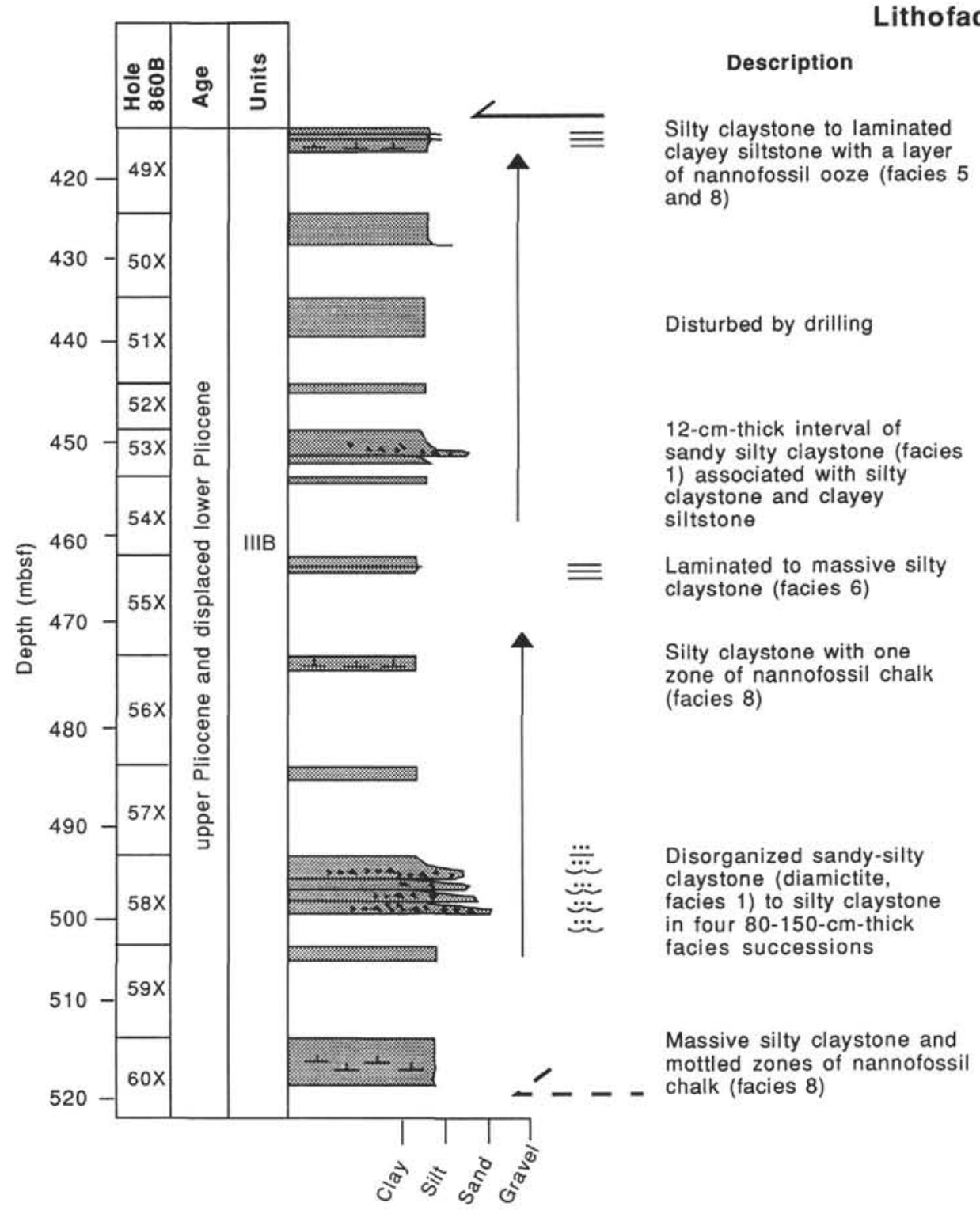

\section{Interpretation}

Low-density fine-grained turbidites and hemipelagic sedimentation

High-density fine-grained turbidite

Mud turbidites

Hemipelagic sedimentation

High-density fine-grained turbidites

Hemipelagic sedimentation

Figure 8. Detailed stratigraphy, sedimentology, and interpretation of the facies between the sheared zone and thrust fault in Unit III, Site 860. Arrows indicate cyclicity. See Table 1 for an explanation of the facies types. Key as for Figure 4.

lation, with the coarsest material at depths of about 50,120-130, and 240-280 mbsf (Diemer and Forsythe, this volume).

At the northern transect sites, the sand-size fraction is predominantly very fine or fine (Fig. 10). The sand grains range generally from angular to subangular at all three sites. The coarse fraction is composed mainly of quartz and feldspars, with hornblende, epidote, and clinopyroxene dominating the heavy mineral fraction. The sand detrital modes are fairly uniform, with the following mean values: QFL\%Q 31, QFL\%F 35 and QFL\%L 34 (Marsaglia et al., this volume), where $\mathrm{Q}=$ total monocrystalline and polycrystalline quartz grains, including chert; $\mathrm{F}=$ total feldspar; and $\mathrm{L}=$ unstable lithic grains. The sediments have a significant volcanogenic component, and some sandy beds consist of up to $20 \%-35 \%$ glassy volcanic material. Primary ash layers are sparse. Vesicle-rich vitric clasts in the volcaniclastic sands are abundant in the Pleistocene section, whereas the upper Pliocene section at Site 860 is rich in brownish to blackish, slightly vesicular or blocky volcanic grains (Strand, this volume). Mica, orthopyroxene, tremolite-actinolite, olivine, and "sialic" accessories (garnet, zircon, apatite, tourmaline, and sphene) occur in minor amounts. Clay minerals consist mainly of hydromica and chlorite, whereas smectite is a common minor component (Kurnosov et al., this volume).

\section{Interpretation}

Site 859 and the uppermost part of Site 860 are dominated by hemipelagic sedimentary deposits (Facies 8 ) and fine-grained (Facies 5) to mud turbidites (Facies 6). The mottled silty clay to clayey silt (Facies 8) represents a typical lower trench-slope cover. The criteria for recognizing fine-grained and mud turbidites adopted from Piper and Stow (1991) include low microfossil content, lack of bioturbation, and thick massive mud beds of uniform composition. The sandy portions (Facies 3 and 4) are defined as high- to low-density distal turbidites (Pickering et al., 1986, 1989), and the graded sand-silt couplets (Facies 4) are consistent with incomplete Bouma sequences. Unit II of Site 860 is characterized by predominantly mud-turbidite (Facies 6 and 7) and some hemipelagic deposition, whereas Unit III is characterized by at least four repetitions of high-density to low-density fine-grained tur- 


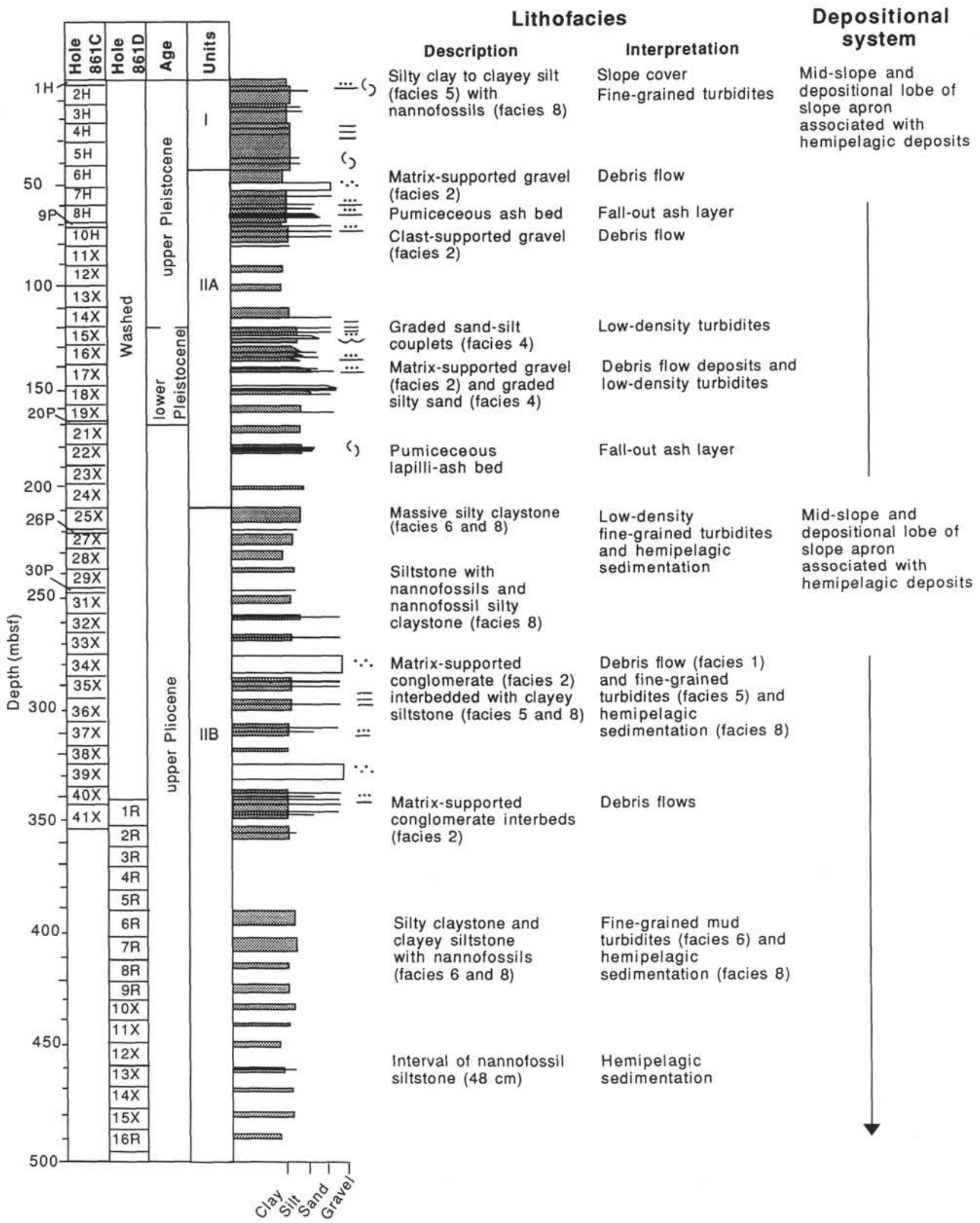

Figure 9. Stratigraphy, sedimentology, and interpretation of the sequence cored at Site 861. See Table 1 for an explanation of the facies types. Key as for Figure 4.

bidites overlain by hemipelagic intervals, which probably resulted from imbrication by thrust faults. The detailed section between the sheared zone and the thrust fault (Fig. 8) also shows primary cyclic sedimentation, with turbidites interbedded with hemipelagites. The disorganized sandy silty claystones with dispersed pebble- to granulesized lithic clasts (Facies 1) closely resembles the Facies C1.1 of
Pickering et al. $(1986,1989)$ and are interpreted as having been transported in high-density turbidity currents. The thin intraformational conglomerate beds (Facies 2) were formed by local reworking processes. The matrix-supported to clast-supported gravel units (Facies 2) at Site 861 represent debris-flow deposits (Pickering et al., 1986, 1989). The sequences in which gravelly or sandy basal portions grade 

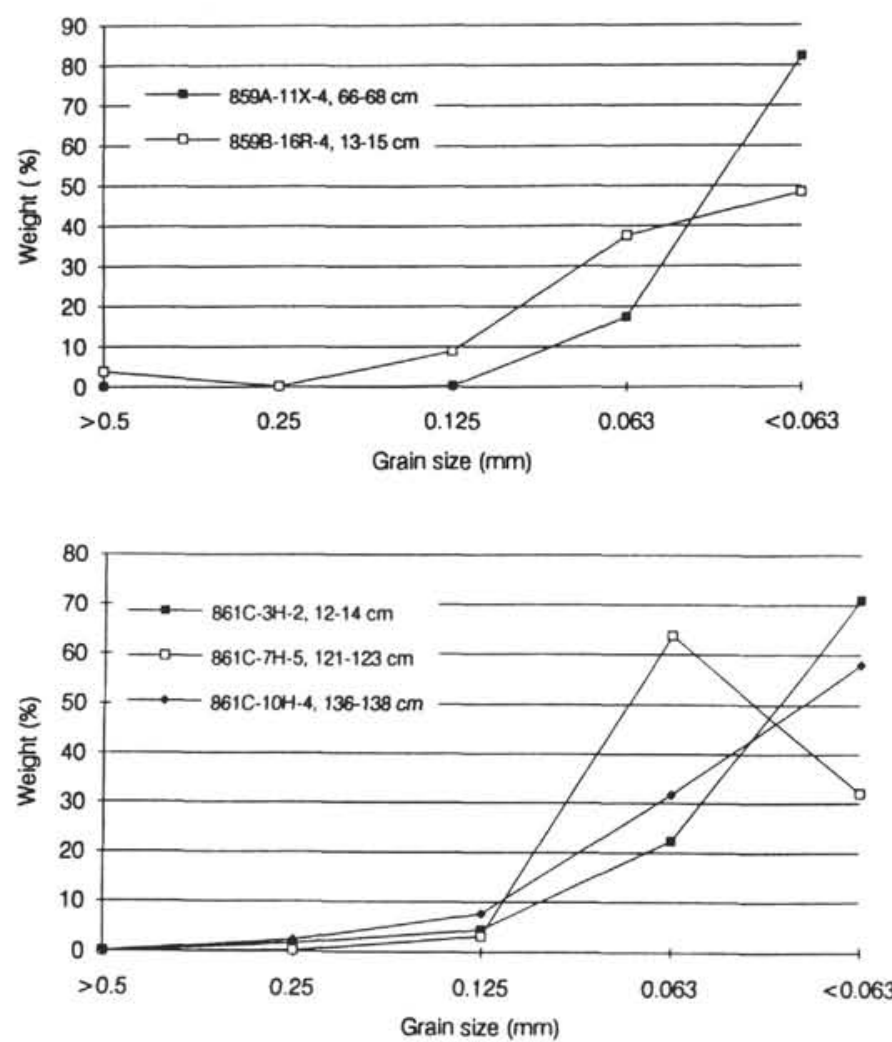
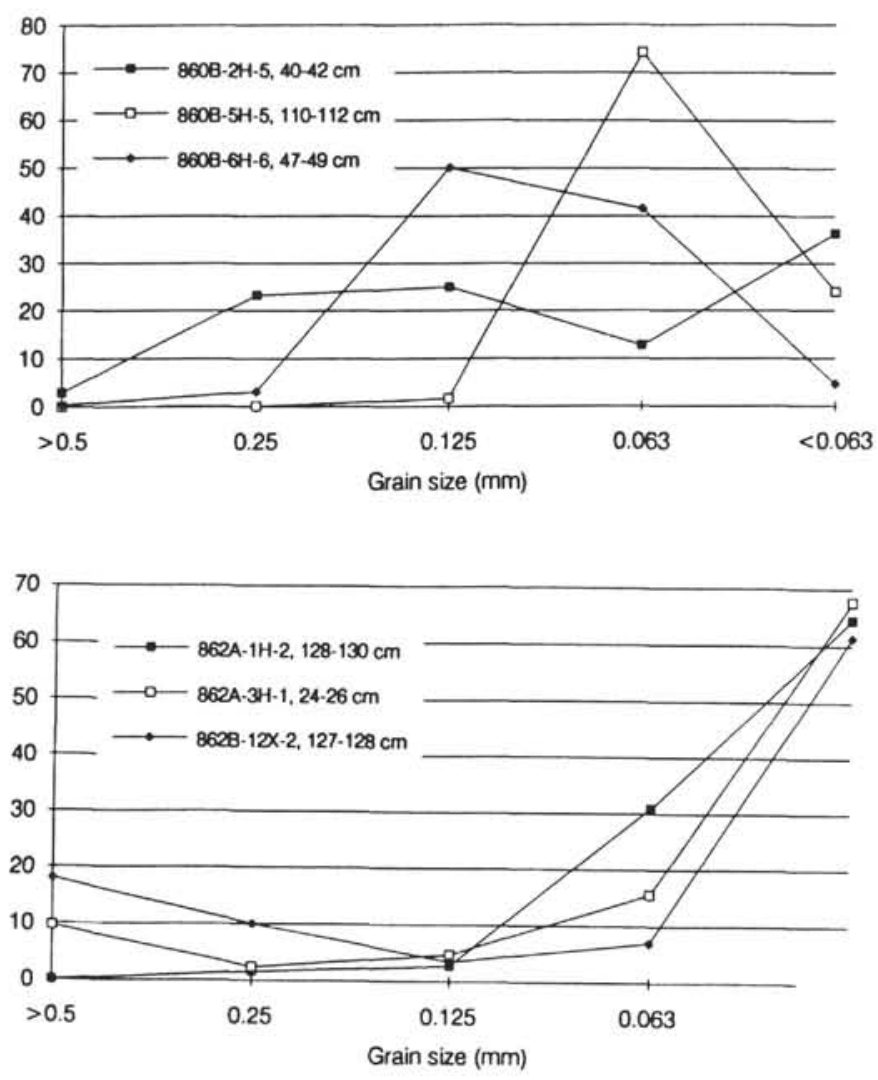

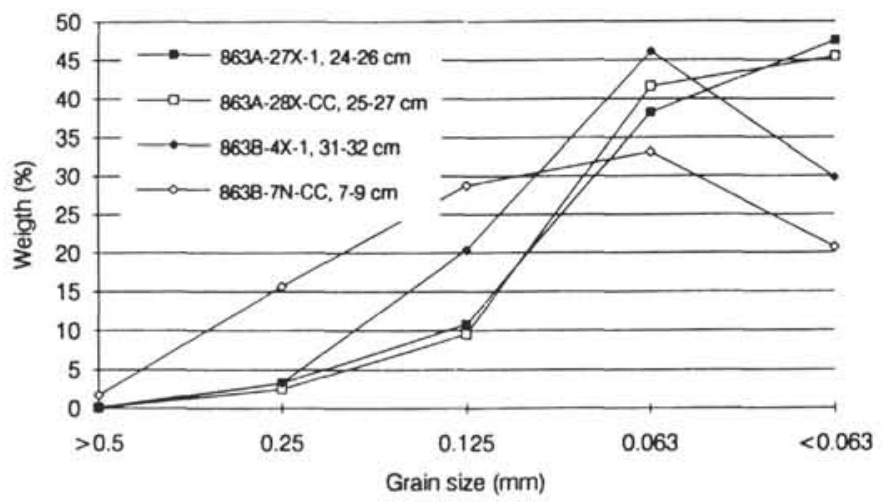

Figure 10. Examples of grain-size distribution curves for the sieved coarse clastic portions of sanuples from Leg 141.

upward to laminated to cross-laminated and then bioturbated silty clay represent partial Bouma sequences, whereas the silty claystone to clayey siltstone in Unit III reflects fine-grained turbiditic and hemipelagic deposition. Most sediments of the northern transect sites represent deposition from slumps, debris flows, turbidity currents, or suspension processes, greatly resembling trench-slope sedimentation described by Underwood and Bachman (1982). The debris-flow deposits are more abundant in the proximal regions (i.e., at Site 861), and some of the fine-grained sand and mud may have evolved from these debris flows, eventually forming fine-grained turbidites (Einsele, 1991). Some debris flows must have traveled farther down the slope than others, resulting in interbedded debris-flow and turbidite deposits.

\section{Site 863}

\section{Description}

Site 863 consists of two lithological units differing to some extent from those of the northern transect (Fig. 11; Shipboard Scientific
Party, 1992e). Subunit IA (0-46.6 mbsf) is composed of $4 \mathrm{~m}$ of silty clay to clayey silt overlying upper Pleistocene sulfide/organic-rich silty clay to clayey silt, with minor fine-grained sand. The thin sandy interbeds are typically laminated and locally show inverse grading or small basal scours. Subunit IB (46.6-104.4 mbsf) consists of similar, but more lithified upper Pleistocene lithologies. Unit II (104.4 to $742.9 \mathrm{mbsf}$ ) is composed of lower and upper Pleistocene sandstone and bioturbated siltstone (Facies 3 and 4), silty claystone (Facies 5), and some interbeds of nannofossil chalk or fine-grained sediments with nannofossils (Facies 8). Most of the bedding in Unit II is steep to vertical. Some sandstone beds in Subunit IIA (104.4-220.3 mbsf) are fine-grained and thinly laminated to cross-laminated. Subunit IIB (220.3-405.5 mbsf) consists typically of 15 to 20 -cm-thick intervals of fine- to medium-grained graded to massive sandstone-sandy siltstone couplets (Facies 4 ) or 1 to 2 -cm-thick beds of fine-grained, graded sandstone (Facies 3) that are interbedded with bioturbated sandy silty claystone. The sandstone becomes more carbonatecemented with increasing depth. Typical fining-upward sequences in 


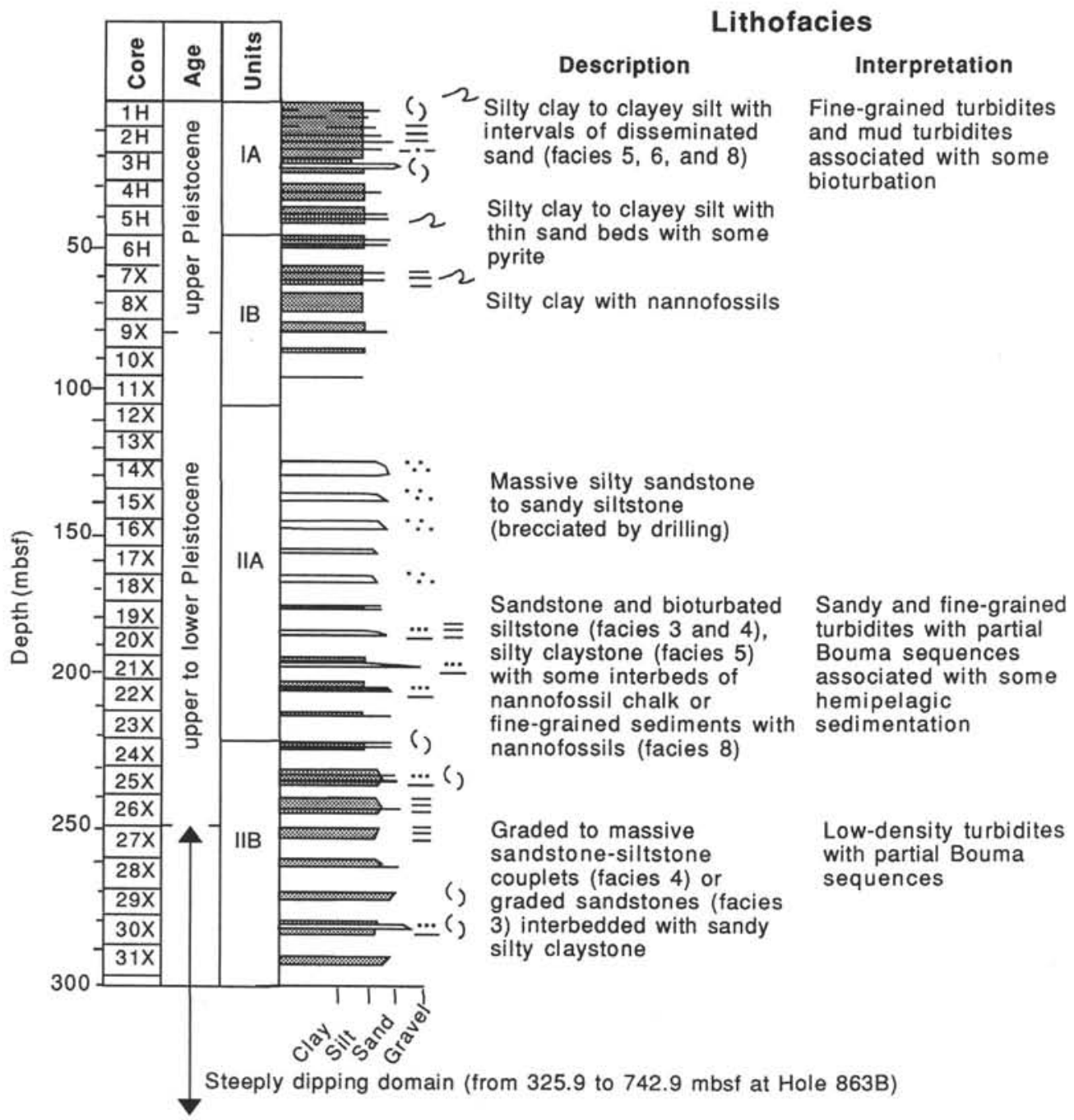

\section{Depositional system}

Depositional lobe of slope apron associated with hemipelagic deposits

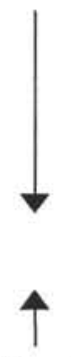

Depositional lobe of submarine fan fed by canyon in trench/slope

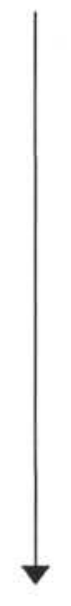

Figure 11. Stratigraphy, sedimentology, and interpretation of the sequence cored at Hole 863A. See Table 1 for an explanation of the facies types. Key as for Figure 4.

Subunit IIC (405.5-742.9 mbsf) are 5-20 cm thick and consist of graded to massive, sometimes cross-laminated sandstone-laminated siltstone couplets followed by massive silty claystone (Fig. 12). The sandstones show scoured bases and sometimes load structures.

The mean grain size is somewhat larger than at the northern transect sites (Diemer and Forsythe, this volume) and the sand fraction is predominantly very fine to fine with a wider grain-size distribution (Fig. 10). The sandstones vary in composition from lithic to feldspathic arenites and the sand detrital modes are fairly uniform with relatively similar amounts of quartz, feldspar, and lithic grains. Other common framework grains include hornblende, epidote, pyroxene, and biotite. The hydrothermal alteration at Site 863 below $400 \mathrm{mbsf}$ is indicated by an extensive secondary smectite formation. Hydrothermal circulation also leads to an alteration of volcanic glass to smectite, an increase in secondary quartz and recrystallization of nannofossils to micrite under low-temperature conditions, and presence of secondary carbonate in veinlets and cavity fillings (Kurnosov et al., this volume; Prior et al., this volume).

\section{Interpretation}

Most of the Unit II sediments are interpreted as turbidite sands, silts, and clays that are largely similar to the modern submarine canyon-fed fan deposits found farther north in the trench (Thornburg and Kulm, 1987; Thornburg et al., 1990), whereas Unit I is interpreted as more likely to have been deposited by slope apron processes. Slope aprons generally include coarse- to fine-grained turbidites and hemipelagites, slides and debrites (Pickering et al., 1986, 1989). The lamination and inverse grading in the thin sandy interbeds of Unit I may indicate bottom-current reworking and represent contourites (Shanmugam et al., 1993). Unit II consists predominantly of partial Bouma sequences $\left(\mathrm{T}_{\text {acde }}, \mathrm{T}_{\text {bcde }}, \mathrm{T}_{\text {cde }}\right)$ and the beds generally lack the basal or middle parts of a Bouma sequence. The beds resemble the Facies C2.2 and C2.3 of Pickering et al. $(1986,1989)$ and are interpreted as having been transported in turbidity currents ranging from high- to low-concentration and probably deposited in outer fan lobes. The only large canyon that may have contributed sediment at Site 863 is located southeast of the Triple Junction (Fig.1).

\section{Taitao Ridge (Site 862)}

\section{Description}

A 22-m-thick succession of upper Pliocene to Quaternary sediment (Unit I) overlies intercalated submarine basalt, dacite, and rhyolite flows (Unit II) at Site 862 (Fig. 13; Shipboard Scientific Party, 1992d). Subunit IA is $6 \mathrm{~m}$ thick and consists of silty clay to clayey silt, clay, and graded to laminated silty fine sand (Facies 4 and 5). Some sandy intervals are cross-laminated, with internal erosional surfaces, 


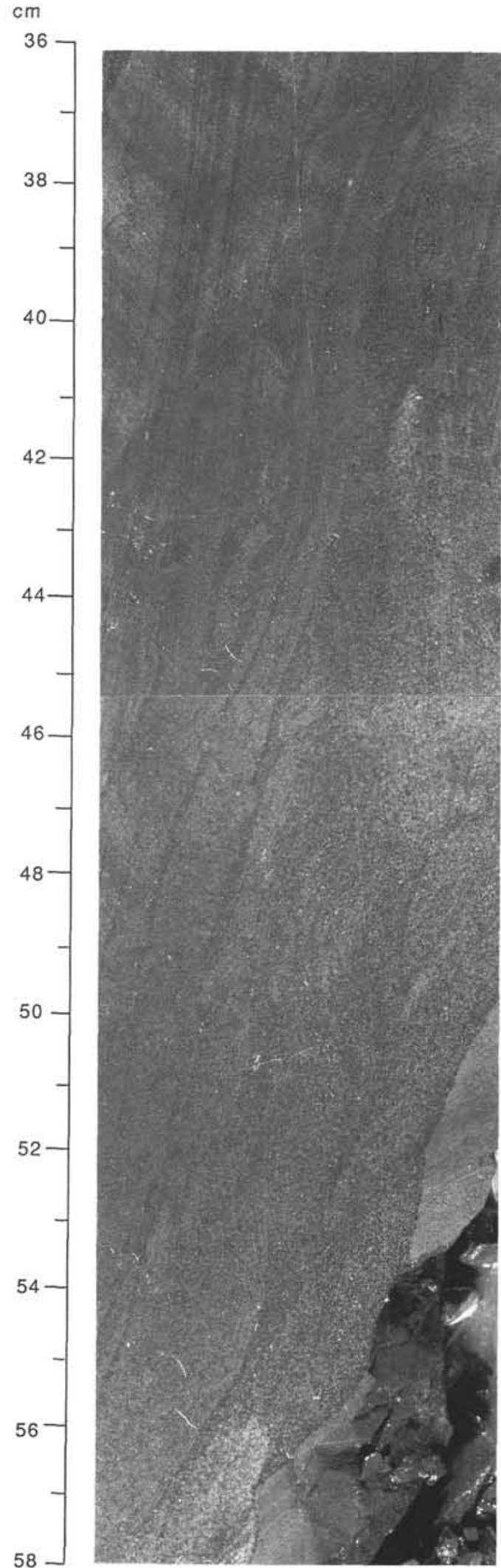

Figure 12. A typical graded to massive fine-grained sandstone-siltstone couplet (Facies 4) in Subunit IIC at Site 863. The basal contact is slightly scoured and the siltstone is convolute to horizontally laminated, followed by a massive silty claystone interval some $7 \mathrm{~cm}$ in thickness. Sample 141-863B-48R-3, 36-58 $\mathrm{cm}$. See Table I for an explanation of the facies types. and bed thicknesses are usually $<5 \mathrm{~cm}$ (Fig. 14). Subunits IB is more lithified (6-21 mbsf) and IC hydrothermally altered (21-22 mbsf), but similar in composition to Subunit IA. The matrix-supported conglomerate observed in Hole $862 \mathrm{~A}$ probably represents the basal lithology overlying the major volcanic sequence. The sand-sized fraction at Site 862 is predominantly very fine to fine sand with a wider distribution of sand grain sizes associated with relatively high proportions of a coarse sand-sized fraction (Fig. 10). The sandy sediment is relatively uniform in composition, and similar to that of the other Leg 141 sites (Marsaglia et al., this volume). The Site 862 sediments consist of $5 \%-40 \%$ volcanic glass fragments and more than 10 intercalated, locally derived vitric ash layers (Strand, this volume).

\section{Interpretation}

The graded intervals in Subunit IA represent deposition from distal low-density turbidity currents, mostly in the form of suspension fallout. The cross-laminated sandy intervals may represent contourites or sands reworked by other type of bottom currents (Stow and Lowell, 1979; Shanmugam et al., 1993), or they may have been produced by currents generated by contemporaneous submarine neartrench eruptions. Gradational lower bases, sharp upper contacts, internal erosion (i.e., reactivation surfaces), and cross-lamination present in the Site 862 cores are not diagnostic for turbidites and were produced mostly by traction or combined traction transport. The wider distribution of sand grain sizes associated with relatively high proportions of the coarse sand-sized fraction is a further indication of reworking and sorting of the sand (Fig. 10). This reworking was related into sporadic increases in current velocities whereas turbidites are characterized by decreasing current velocities. Unit II represents in-situ, but highly fractured, pillowed flow-units composed of a bimodal suite of basaltic and dacitic to rhyolitic eruptive materials (Shipboard Scientific Party, 1992d).

\section{Depositional Systems}

The facies of the northern transect can be broadly grouped into two outer margin depositional systems: the basin plain/trench system and the overlying slope aprons associated with hemipelagic deposits. The definition now used follows the terminology reviewed by Pickering et al. (1989) and Stow (1992). The sand composition in the lowermost section at Site 859 is quartzose, and the dominant lithic materials are metamorphic fragments, possibly a further indication that the lower portions at the site represent trench fill derived from along-strike submarine canyons, whereas the uniform sand compositions at Sites 860 and 861 and in the upper part of Site 859 represent slope deposits with uniform onshore sources (Marsaglia et al., this volume; Fig. 15), supporting our interpretations regarding the pattern of the depositional systems in the northern transect (Figs. 4, 5, 6, and 9). We chose to divide the slope apron depositional system into an upper slope and channel facies association, a mid-slope facies association, and a depositional lobe facies association. Much similar type of slope apron facies associations can be distinguished both on passive- (e.g., Hill, 1984) and active-margin settings (e.g., Underwood and Bachman, 1982). In both these tectonic settings vertical facies sequences are generally related to slope progradation, sea-level fluctuation and especially in active convergent margins to tectonic activity. The slope aprons constitute stacked, predominantly distal depositional lobe environments at Site 859 (Figs. 4 and 5), whereas Site 860 marks a transition from slope/trench fill to mid-slope and depositional lobe environments (Fig. 6) and the Site 861 slope aprons consist entirely of mid-slope to depositional lobe associations (Fig. 9). Tectonic effects led to an overall shallowing-upward succession in the basin, and small slope basins commonly develop on an accretionary prism, thus producing a slightly upward-coarsening sequence in the upper portions of Sites 860 and 861. Reliable estimations of an accumulation rate for the northern transect sediments are difficult because of the tectonic thickening or struc- 


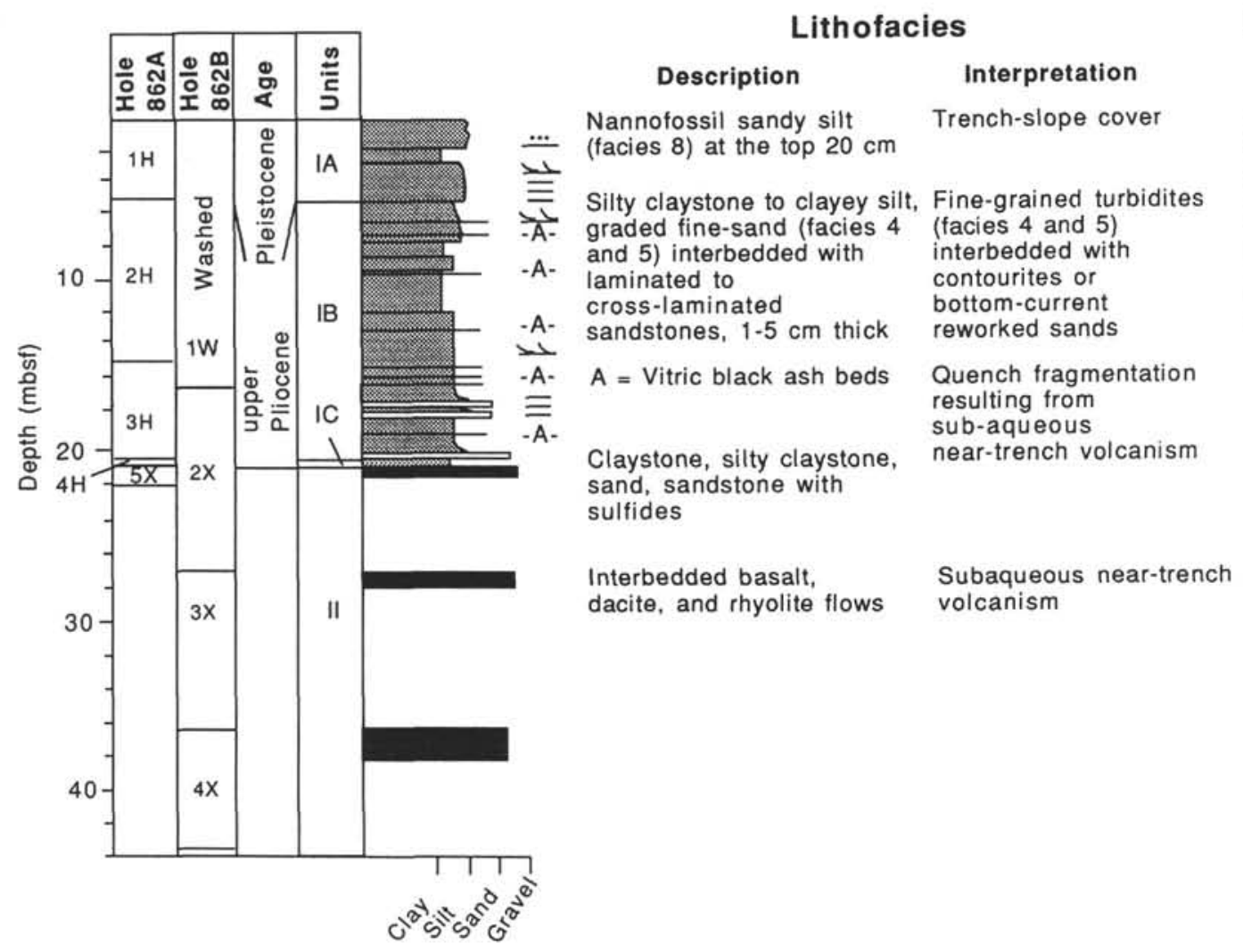

\section{Depositional system}

Depositional lobe of slope apron associated with hemipelagic deposits, some contourites or bottom-current reworked sand owing to contemporaneous subaqueous volcanism

Figure 13. Stratigraphy, sedimentology, and interpretation of the sequence cored at Site 862. See Table 1 for an explanation of the facies types. Key as for Figure 4 .

tural disturbance. Furthermore, the Pleistocene record at Site 859 is only $10 \mathrm{~m}$ thick (Fig. 3) and the biostratigraphic, paleomagnetic, and the occurrence of slump folds indicate a possible major hiatus (Behrmann et al., this volume). An estimated accumulation rate for the Pleistocene and Pliocene slope-apron sediments at Site 860 is $47 \mathrm{~m} / \mathrm{m}$.y., and at Site 861 it is about 100 m/m.y. (Behrmann, Lewis, Musgrave, et al., 1992).

In some cases the slope may be cut by canyons or gullies that feed isolated lobes in the area at the base of the slope or it may be smoothed and molded by bottom currents (Stow, 1992). That may be the case at Site 863 , where the facies characteristics within the depositional systems differ from those defined from the northern transect sites. The Site 863 sediments are interpreted as submarine canyon-fed deposits, whereas the upper parts were more probably deposited by slope apron processes, as depositional lobes associated with hemipelagic sedimentation (Fig. 11). The sand compositions in the canyon-fed fan deposits exhibit a wider diversity in the lithic content than in the upper portions of the site, which show a composition similar to those of other slope apron deposits at the northern transect (Fig. 15). The sedimentary lithic fragments that characterize the fan deposits might have been produced by rapid downcutting in the canyon. They may be eroded accretionary prism sediments or they represent the eroded sedimentary cover of the now-denuded Taitao Peninsula (Marsaglia et al., this volume; Fig. 1). Sediment accumulation rates in the upper flat-bedded Pleistocene domains at Site 863 (Figs. 3 and 11) are estimated to be around $200 \mathrm{~m} / \mathrm{m}$.y. (Behrmann et al., this volume).

The sediments drilled at Site 862 also defines thin depositional lobe environments associated with a few hemipelagic deposits, but with a significant proportion of the fine-grained sandy deposits reworked by contour currents or other bottom currents (Fig. 13). An estimated rate of accumulation for these sediments was about 10 $\mathrm{m} / \mathrm{m}$.y. (Behrmann et al., this volume) indicating anomalously slow sedimentation or erosional periods. The similarity of Site 862 depositional environment and sediment composition to those of other Leg
141 sites (Fig. 15) suggests that this ridge was connected to the shelf during the late Pliocene, prior to spreading-ridge subduction in this region, and could not have been an isolated ridge on the subducting plate. Furthermore, the presence of locally derived primary ash layers in the Site 862 sediments suggests that ridge volcanism was concurrent with a mainland connection.

\section{SEDIMENTATION HISTORY NEAR THE CHILE TRIPLE JUNCTION}

Sedimentation in the trench and accretionary prism slope basins adjacent to the spreading-ridge subduction region is controlled by climate and tectonics (Figs. 16, 17, and 18). A proximal source, narrow continental shelf, and steep drainage gradients are diagnostic features of the Chile margin.

\section{Climatic Control over Outer Margin Depositional Systems}

The Patagonian Andes were already glaciated some time before approximately $4.6 \mathrm{Ma}$ ago, and the glaciers oscillated stepwise between 2.4 and 1.2 Ma ago (Rabassa and Clapperton, 1990). According to Mercer $(1976,1983)$, the greatest Patagonian glaciation occurred in the early Pleistocene, soon after 1.2 Ma, when the glaciers terminated on the Pacific shelf south of latitude $43^{\circ} \mathrm{S}$ and reached the Atlantic continental shelf (Rabassa and Clapperton, 1990). The middle Pleistocene may have been characterized by a prolonged interglacial or shorter-period glaciation.

The grain-size variations and cycles observed at Site 859 may be partly related to changes in the influx of glacial sediments (Figs. 5 and 18). In the lower sections, the situation may be complicated by tectonic thickening or structural disturbance associated with subduction accretion. The two slightly upward-fining cycles in Subunit II at Site 859 correlate with short periods of temperate water conditions in an 

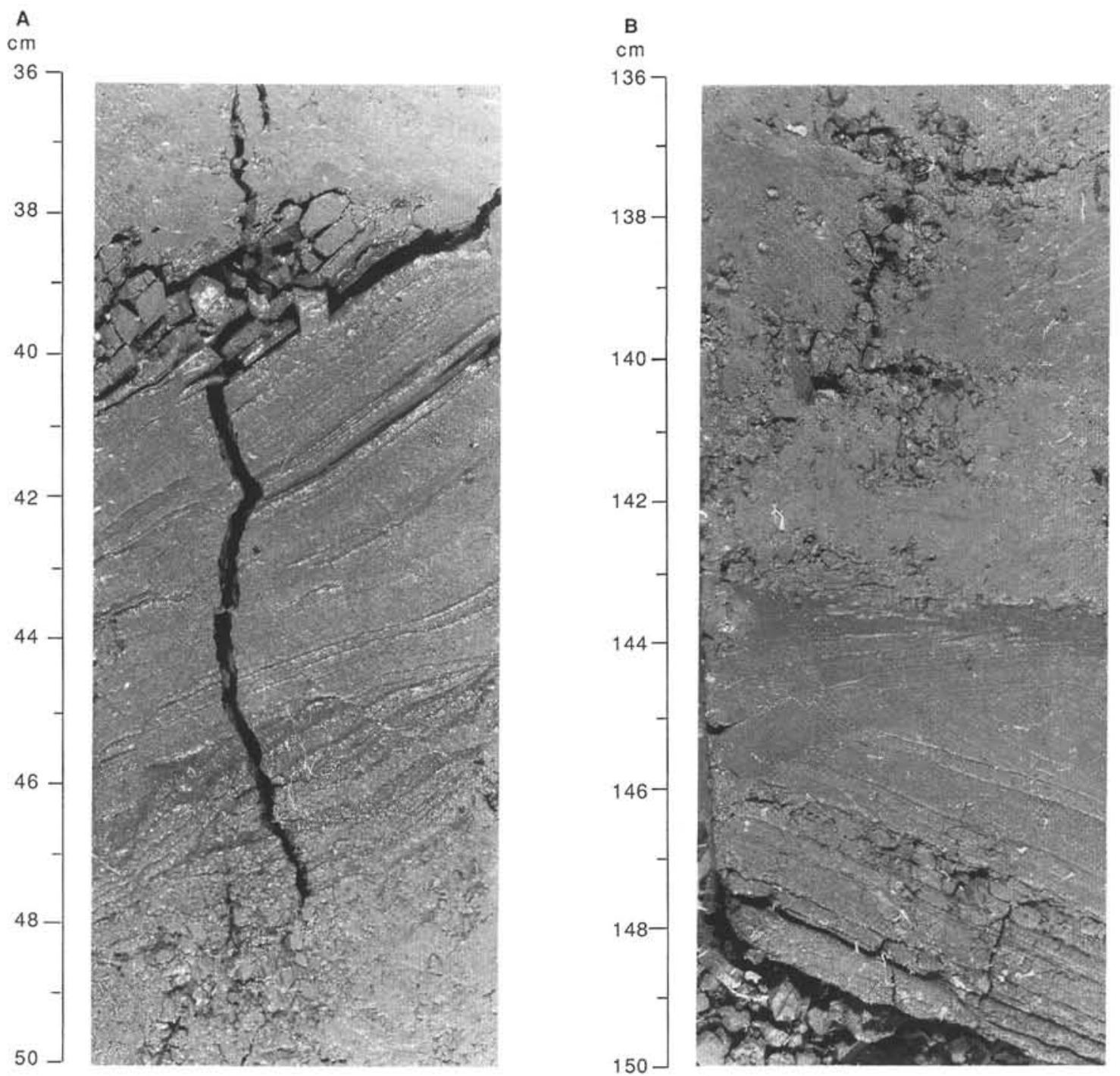

Figure 14. Typical internal lamination in fine-grained sandstones at Site 862 . A. Cross-laminated silty sandstone interval $10 \mathrm{~cm}$ thick showing reactivation surfaces, a gradational lower contact, and a sharp upper contact in Subunit IB. Sample 141-862B-2X-1, 36-50 cm. B. Silty sandstone showing low-angle lamination and a sharp upper contact in Subunit IB. Sample 141-862B-2X-1, 136-150 cm.

otherwise cold-water marine paleoenvironment during the Pliocene as indicated by planktonic foraminifers (Shipboard Scientific Party, 1992a). Water conditions during the late Pleistocene were temperate to subtropical. Difficulties in detail occur trying to link the sedimentary characteristics of the Leg 141 sites with the global glacioeustatic curve of Haq et al. (1987, 1988), although most of the terrigenous material was delivered to a slope basin during lowstand conditions (Fig. 18; Haq, 1991). It is generally the case that during glacial maxima sedimentation on the shelves and adjacent deep sea were influenced by global lowstands of sea level (Shanmugam and Moiola, 1982, 1988). The glacial influence on the trench-slope basin near the Chilean coast, however, is relatively well indicated in the Leg 141 sedimentary record. The trench-slope basin was dominated by terrigenous sediment input and received siliciclastics in significant amounts through transport by turbidity currents and related gravity flows, especially during the middle late Pliocene, early Pleistocene, and during fluctuating glacial conditions of the late Pleistocene (Figs. 17 and 18). The major terrigenous sediment input periods correlate well with the peak of Pliocene and Pleistocene glacial advance along the Southern Andes as reviewed by Clapperton (1990). The fresh feldspar, angular quartz, and angular, unaltered volcanic glass grains in the sediments are inferred to be further evidences for cold climate and point to the glacially influenced depositional environment. The glacial influence on the trench-slope basin near the Chilean coast was intermittent, and when the shelf areas were covered by ice, they were subjected also to glacial erosion. Depending on the glacial affinity prevailing at that time, some of the coarsest units could have been initiated by sudden, high-discharge meltwater events at the base of the ice sheet, or perhaps related to seasonal peaks in meltwater discharge. Glacial ablation along the shelf edge would serve as a distribution method that could bypass the shelf and funnel sediment out onto the continental slope. Sediment release from ice shelves generally takes place close to their grounding lines (Drewry, 1986), so that in the case of the Chile margin, when the grounding line was proximal to the shelf edge, large quantities of material could have been released at the shelf edge and redistributed by gravity-flow processes. The debrisflow deposits are more abundant in the proximal regions and some of the fine-grained sand and mud may have evolved from these debris flows. Some debris flows must have traveled farther down the slope than others, resulting in interbedded debris-flow and turbidite deposits, resembling a situation recorded by Wright and Anderson (1982) for sediments deposited in the Weddell Sea. During transitions from 


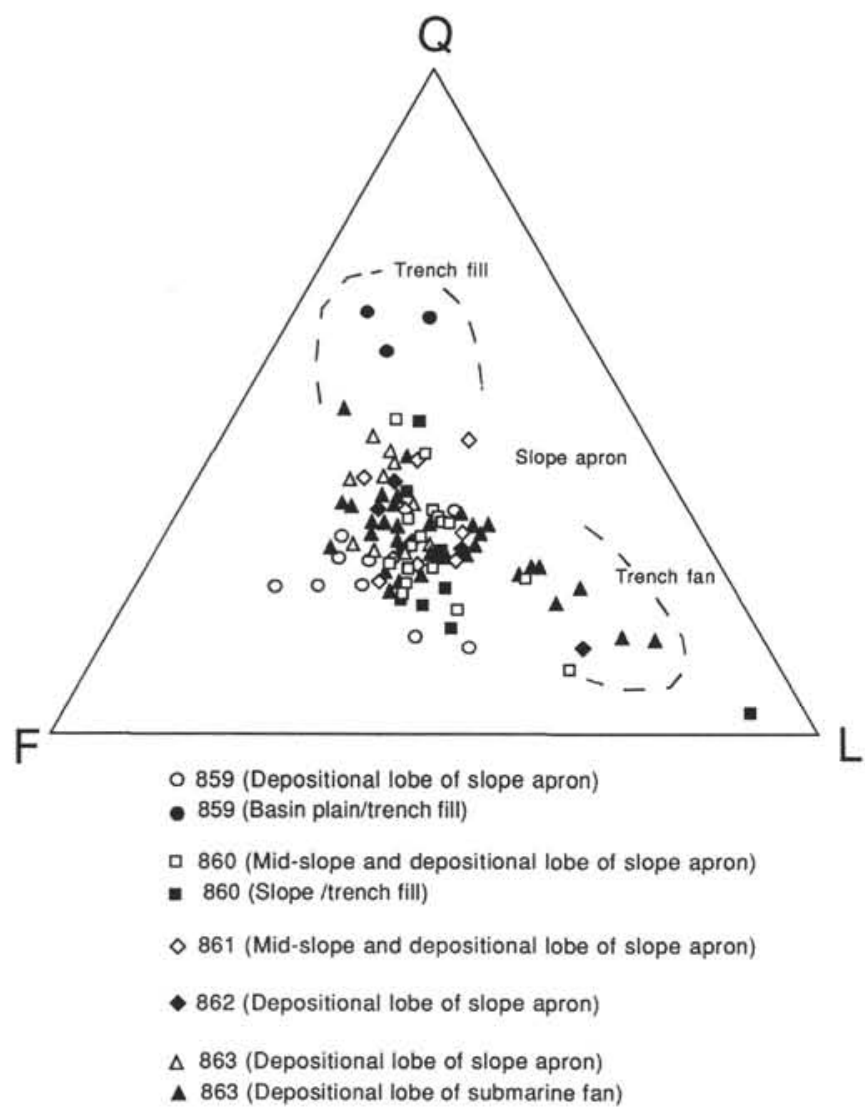

Figure 15. Ternary plot of QFL data (Marsaglia et al., this volume) grouped by the depositional environments within each site. Fields within the diagram demonstrate a slight relation between composition and depositional environment.

glacial to interglacial conditions when glacial ice was retreated the Chilean shelf setting may have turned from partially ice-grounded and erosive to more depositional and probably causing some sediment starvation in the slope setting. The Holocene has been characterized by reduced glacial conditions and increased biogenic productivity. A good modern analogue for glacial maximum conditions in offshore Chile is the northern Antarctic Peninsula, which has been very sensitive to effects of fluctuating ice-sheets (Kennedy and Anderson, 1989; Pope and Anderson, 1992). Today ice shelves exist on the eastern coast and locally on the western coast and iceberg calving is the primary source of ablation; basal melting is important only locally. During the last glacial maximum, grounded ice covered nearly the entire continental shelves, and possibly extended out to the continental shelf breaks (Kennedy and Anderson, 1989).

\section{Tectonic Control over Outer Margin Depositional Systems}

Much of the toe of the slope is currently undergoing uplift as the Chile Ridge is subducted (Behrmann, Lewis, Musgrave, et al., 1992), which lead to a shallowing of the basin and makes it possible to form a coarsening-upward succession (Sites 859 and 860; Figs. 4 and 6, respectively). Cloos (1993) estimates that a spreading ridge-related cycle of isostatic uplift and subsidence in a forearc region could be as much as 2 to $3 \mathrm{~km}$. At Site 860 the subduction accretion was characterized by thrust faults causing a rapid tectonic uplift of the trenchslope in the order of $2000 \mathrm{~m}$ and a shallowing of the basin from abyssal to middle bathyal water depth (Fig. 18; Behrmann et al., this volume). This shallowing of the basin is evident also at the Site 861, where the sediment succession shows more proximity to the slope and

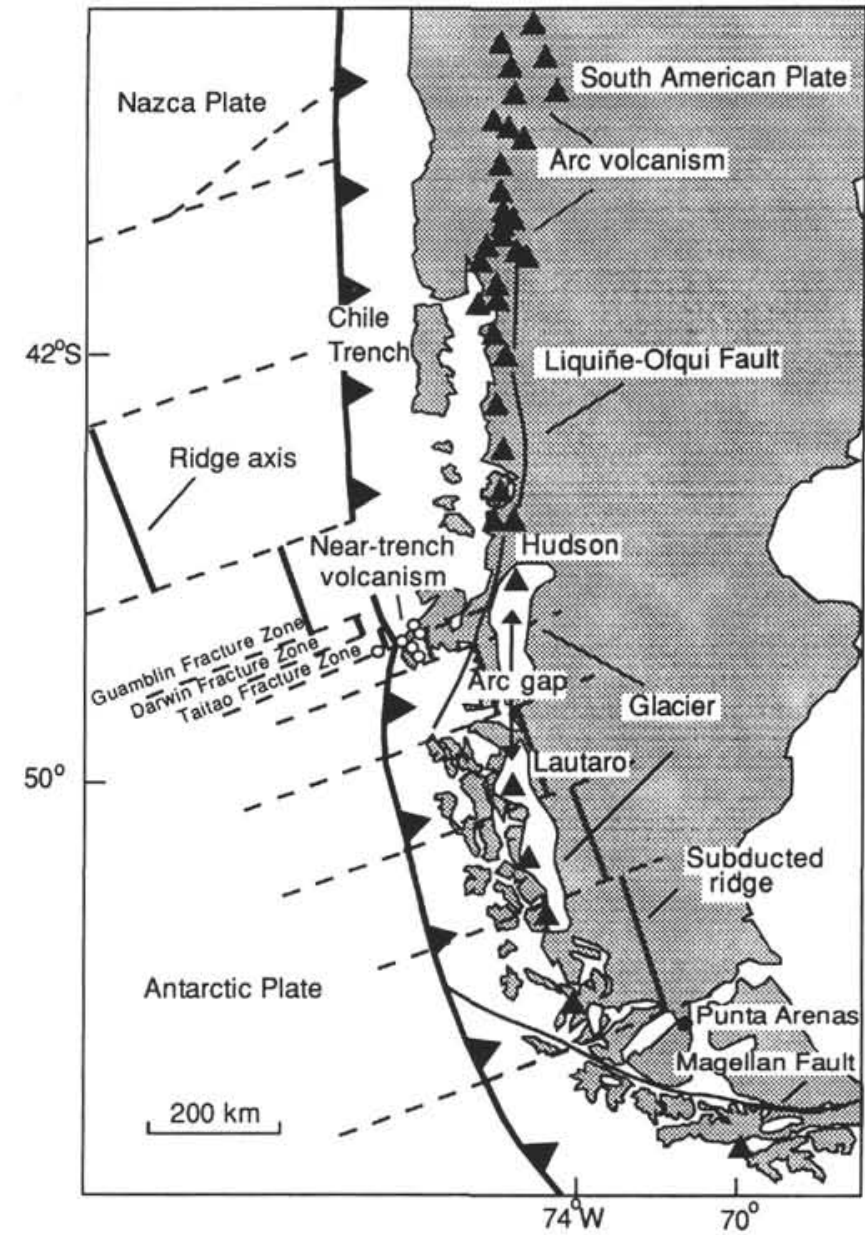

Figure 16. Plate configuration for the Chile margin Triple Junction, the forearc and arc of southern Chile, and the distribution of Pliocene-Quaternary stratovolcanoes (after Simkin et al., 1981) and present-day ice glaciers (after Rabassa and Clapperton, 1990). Open circles are anomalously near-trench volcanic centers on the Taitao Peninsula (after Forsythe and Prior, 1992).

benthic foraminifers present indicate abyssal to middle bathyal conditions below 136 mbsf, whereas the Pleistocene assemblages indicate middle bathyal to upper bathyal conditions (Fig. 18; Shipboard Scientific Party, 1992c). Coarsening-upward trench and trench-slope sequences are a typical character in many active convergent margins resulting from plate convergence (Lash, 1985; Thornburg and Kulm, 1987 ) and thus not necessarily directly related to ridge-trench collision. In relation to a passage of the spreading-ridge subduction the accretionary prism was then focused by local subsidence at least 1000 $\mathrm{m}$ and substantially removed at Site 863 (Fig. 18; Behrmann et al., this volume). We conclude that the landward trench slope is undergoing an episode of rapid tectonic erosion.

Tectonic effects related to migration of the Chile Triple Junction caused uplift and exhumation of the Taitao Ophiolite, and the main Andean Cordillera underwent significant differential uplift during the late Cenozoic (Forsythe and Prior, 1992). These effects are likely to have significantly impacted the drainage of sediment to existing shelf and trench-slope basin areas. The quartzose nature of the lowermost section at Site 859 could well be consistent with an uplifted metamorphic source, possibly the northern Taitao Peninsula. North of the Triple Junction the continental divide comprises a semicontinuous series of Pliocene and Pleistocene volcanic centers parallel to the present coastline and Paleozoic to Mesozoic crustal complexes of 

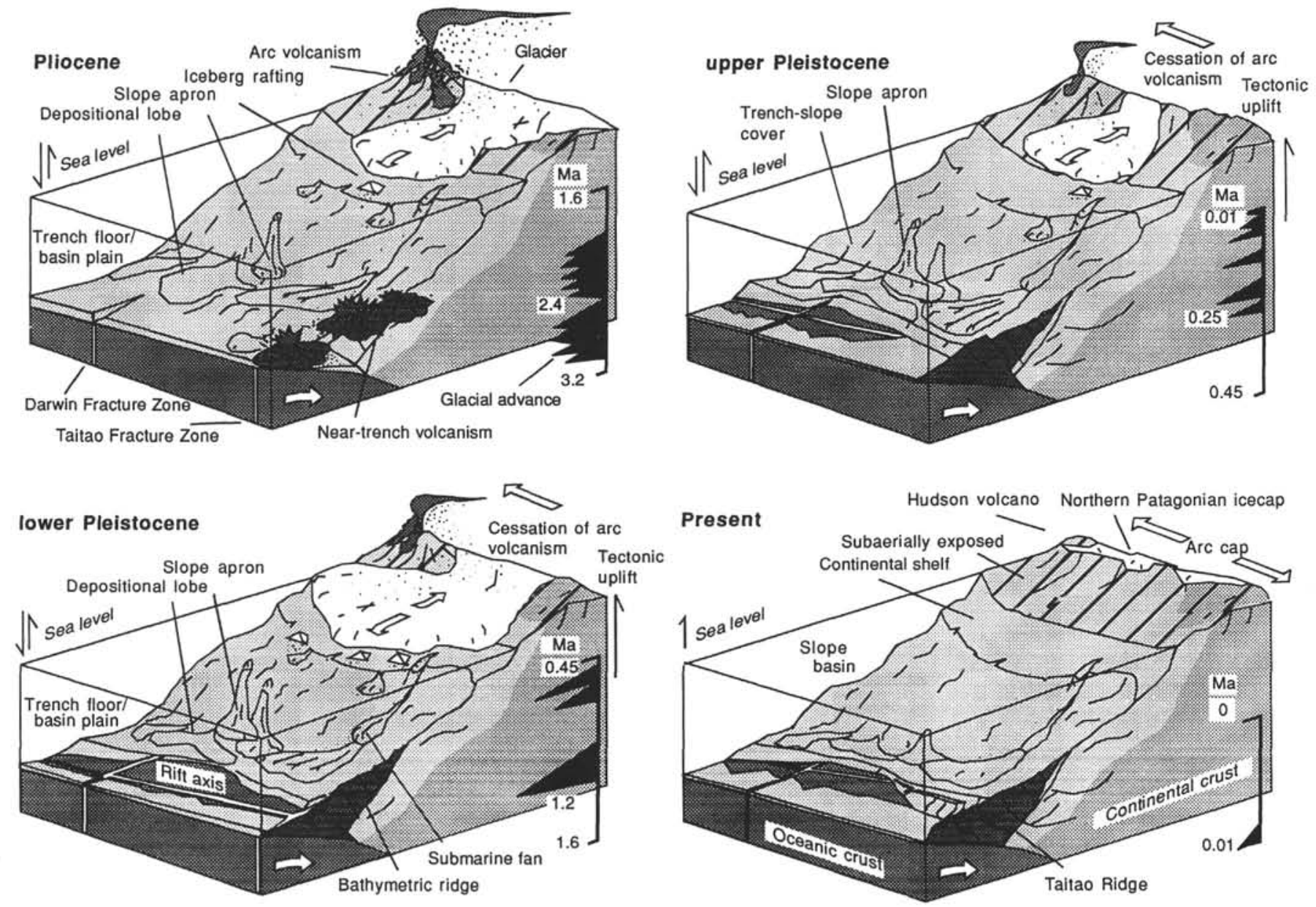

Figure 17. Schematic block diagrams showing the history of the outer margin depositional system of the Chile margin in the vicinity of the Chile Ridge collision zone since the Pliocene. The columns on the right of each blocks illustrate the glacial advance peaks in the Southern Andes during each time interval according to Clapperton (1990).

plutonic and metamorphic rocks, but to the south, the Andes are dominated only by deeper crustal complexes (Forsythe and Prior, 1992). A $300 \mathrm{~km}$ arc gap (Fig. 16) is inferred to be related to the existence of a slab window produced by spreading-ridge subduction (Cande and Leslie, 1986; Forsythe and Nelson, 1985). Volcanic activity progressively ceased along the Andes during the Pliocene-Pleistocene because of migration of the spreading-ridge subduction, leaving its own information in the volcanogenic sediment component of the trench slope. The volcanogenic component in the sandy turbidites is more abundant throughout the Pliocene-lower Pleistocene sections than in the upper Pleistocene and evolved, silicic, vesicle-rich vitric clasts are abundant upsection in the Pleistocene record (Strand, this volume). Decrease or cessation of arc volcanism related to ridge subduction is also recorded from the subduction of the Kula Ridge beneath the Aleutian Arc (DeLong et al., 1978). Nur and Ben-Avraham (1983) identified caps in arc volcanism occurring also when aseismic ridges (e.g., Nazca Ridge and Juan Fernandez Ridge) are subducted and they suggested that this may a general phenomena where anomalous oceanic crust is being consumed.

Furthermore, as a consequence of the ridge-collision the Chilean shelf may encountered intermittent uplift and possible emergence. Thus, the shelf was probably subjected to further erosion in association with glacial erosion. In the Kula Ridge-Aleutian Trench collision site, shoaling and subaerial emergence of the crest of the arc were related to ridge-collision (DeLong et al., 1978). Shoaling was marked by a deep- to shallow-marine transition in sedimentation. The Pacific Antarctic margin provides a good example for tectonic consequences owing to several ridge-trench collisions (Barker, 1982; Barker et al., 1984) and glacially influenced sedimentation (Tucholke et al., 1976). The corresponding arc and forearc areas were tectonically uplifted and eroded in relation to ridge-trench collision. However, following each collision, spreading and subduction both stopped and the margin changed tectonically passive (Barker, 1982) being in that respect different from the Chile margin.

All the above tectonic and volcanic characteristics identified from the Chile margin near the Triple Junction provide good opportunities for the mixing of deeper crustal material (i.e., plutonic and metamorphic rock detritus) with volcaniclastics under glacial and meltwater influence in the uplifted mainland and partially emerged or icegrounded shelf. The tectonically induced uplift and glacial erosion of the shelf were important in regulating sediment supply to the trench-slope and sediment gravity flow processes. Sites south of the Triple Junction show higher metamorphic and sedimentary lithic proportions, probably as a result of uplift and erosion in the Taitao Peninsula region and possibly in relation to the progressive cessation of arc volcanism during northward migration of the ridge subduction. The high sedimentation rates here may correspond to this uplift and increased turbidite activity, to the oversteepening of the forearc slope, and the formation of a submarine canyon north of the Taitao Ridge (Fig. 1; Behrmann et al., this volume). In general, the triple-junction tectonics may serve to locate the formation of the submarine canyons that control the rate of influx and the provenance of the sediment deposited in the trench (Marsaglia and Ingersoll, 1992; Marsaglia et al., this volume). 


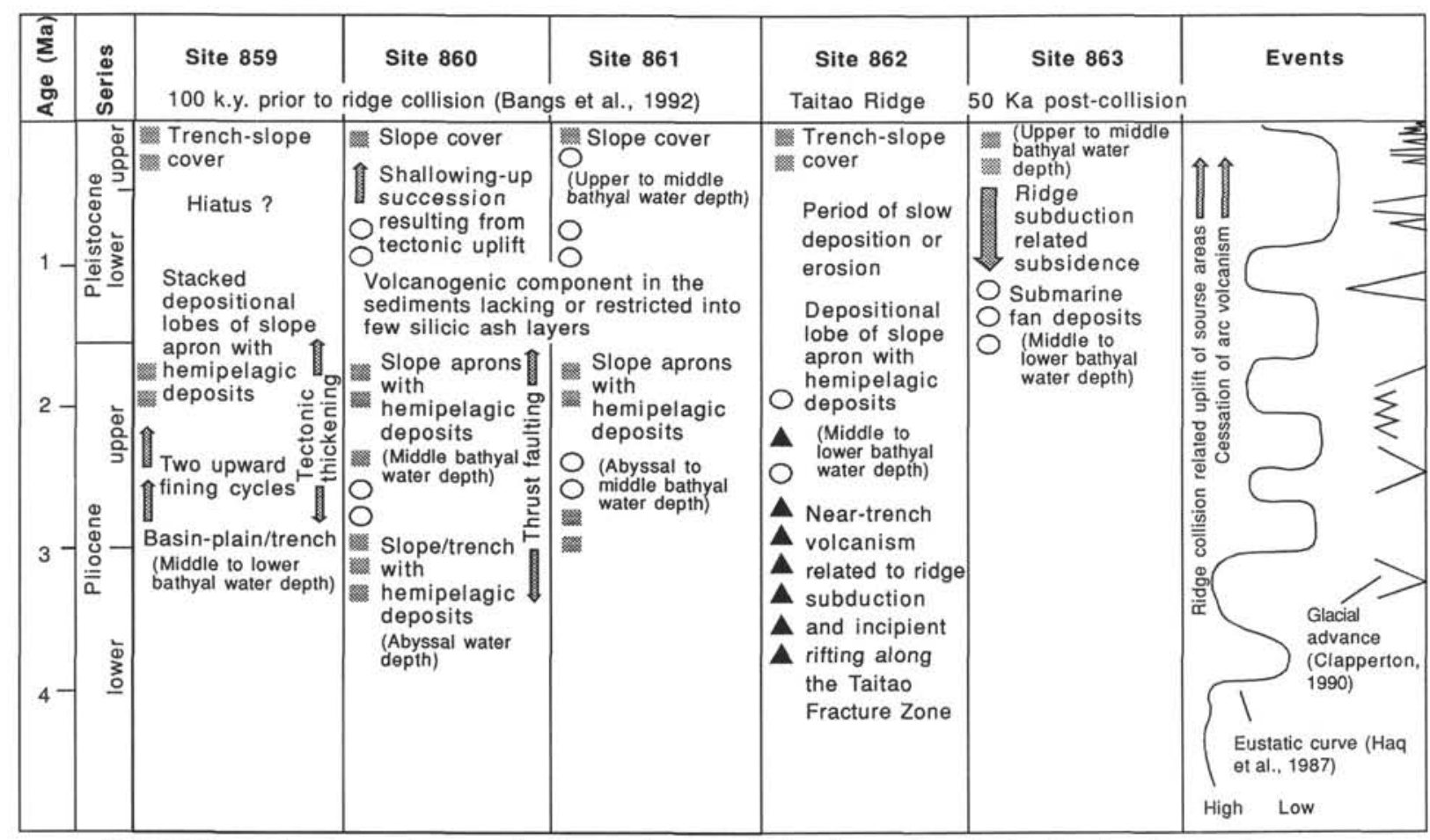

Increase in abundance of coarse clastics Increase in abundance of mud $\boldsymbol{\Delta}$ Near-trench volcanics

Figure 18. Synthesis of changes with time for each Leg 141 sites related to ridge collision and compared with glacial advances in the Southern Andes (after Clapperton, 1990) and eustatic sea-level curve for the late Pliocene to Holocene (after Haq et al., 1987). Paleodepths indicated by benthic foraminifers (Behrmann, Lewis, Musgrave, et al., 1992; Schönfeld and Spiegler, this volume).

Other evolutionary trends that occurred during spreading-ridge subduction along the Chile margin was the emplacement of the neartrench volcanism linked with incipient rifting along the Taitao Fracture Zone during the Pliocene. The generated volcanic ridge is colliding with the trench and may be in the process of being obducted onto the landward trench slope. Pliocene and younger near-trench or forearc volcanism is also observed at the Woodlark ridge-trench intersection, south of the Solomon Islands (Weissel et al., 1982; Johnson et al., 1987). Ancient examples of ridge-subduction and forearc magmatism are found along southern Alaska (Moore et al., 1983; Sisson and Pavlis, 1993) and southwest Japan (Hibbart and Karig, 1990). Marshak and Karig (1977) have postulated that the triple-junction interactions and anomalous near-trench to forearc magmatism are closely related to each other. Thorkelson and Taylor (1989) proposed that ridge subduction processes produce a slab window, which could then cause inducing of plate-edge (i.e., forearc) volcanism.

Subduction of the active spreading Chile Ridge led not only to extensive deformation and some thrust faulting of the trench slope sedimentary strata, but also to hydrothermal alteration of part of the accretionary wedge sediments. The hydrothermal circulation in the Chilean accretionary wedge is most likely created by high heat flow from the subducted spreading ridge. Interstitial waters of the accretionary wedge sediments are heated from below and circulate preferentially as hydrothermal fluids in the more permeable tectonized zones, where the primary sedimentary structure is deformed by faulting and brecciation.

\section{SUMMARY AND CONCLUSIONS}

These investigations were intended to provide information on the processes of sedimentary input and general sedimentary history of a tectonically active trench-slope environment. The sediment composition in the area covered by Leg 141 is greatly influenced by the volcanic activity that took place along the Andean arc and tectonism caused by active spreading-ridge subduction. The Chile margin Triple Junction is an ideal site for studying the effects of a ridge-trench collision, which consequences still are relatively poorly understood geologic phenomena.

1. The outer margin fill on the Chile margin in the vicinity of the Chile spreading ridge-trench collision consists of predominantly structureless muddy sediments, massive to graded sand, sandstones and some gravels and conglomerates. Facies analysis of these sediments indicates deposition from slope failures, turbidity currents, and suspension processes associated with hemipelagic fallout in basin plain/trench to stacked slope apron environments significantly influenced by repeated Pliocene-Pleistocene glaciations. Glacial erosion of the shelf were important in regulating sediment supply to the trench-slope and sediment gravity flow processes.

2. The outer margin setting was dominated by terrigenous siliciclastic sediment input from the Andean volcanic arc, Paleozoic to Mesozoic crustal sources, and the forearc, in slightly varying proportions. The volcaniclastic record reveals the evolutionary trends that occur during spreading-ridge subduction (i.e., the cessation of arc volcanism and the emplacement history of the near-trench volcanism).

3. The allogenic controls of sedimentation that consist of extrabasinal tectonic activity as a distant effect of ridge subduction on the arc tectonism are namely uplift and exhumation of the Taitao Peninsula region and differential uplift of the main Andean Cordillera during the late Cenozoic, Andean arc magmatism, climate and sealevel changes. Other controls include basinal tectonism in the form of rapid subduction accretion characterized by some flat faults, ridgesubduction-related subsidence, and tectonic erosion. The new data on the modern trench, trench-slope, and forearc are important in that they provide models of turbidite sedimentation integrated with all these allocyclic controls (Stow and Shanmugam, 1980; Macdonald, 1991). Outer margin gravity flow processes and depositional system devel- 
opment can give valuable clues to an understanding of the relative influences of variable tectonics (e.g., ridge-trench collision), climate, and sea-level changes.

\section{ACKNOWLEDGMENTS}

The authors wish to thank the officers and crew of the JOIDES Resolution and the ODP technical staff for their efforts and assistance related to Leg 141. We would like to thank our colleague shipboard scientists for their contributions to Leg 141, especially Jan Behrmann, Nancy Lindsley-Griffin, and David Prior for helpful discussions and comments. Part of this work was supported by the Natural Sciences Council of the Academy of Finland. Thanks are also due to Malcolm Hicks for reading the manuscript and defining an expression. Helpful comments by reviewers John B. Andersson and Andreas Wetzel considerably improved the manuscript.

\section{REFERENCES}

Bangs, N., Cande, S.C., Lewis, S.D., and Miller, J., 1992. Structural framework of the Chile Margin at the Chile Ridge collision zone. In Behrmann, J.H., Lewis, S.D., Musgrave, R.J., et al., Proc. ODP, Init. Repts., 141: College Station, TX (Ocean Drilling Program), 11-21.

Barker, P.F., 1982. The Cenozoic subduction history of the Pacific margin of the Antarctic Peninsula: ridge crest-trench interactions. J. Geol. Soc. London, 139:787-801.

Barker, P.F., Barber, P.L., and King, E.C., 1984. An Early Miocene ridge crest-trench collision on the South Scotia Ridge near $36^{\circ}$ W. Tectonophysics, 102:315-332.

Behrmann, J.H., Lewis, S.D., Musgrave, R.J., et al., 1992. Proc. ODP, Init. Repts., 141: College Station. TX (Ocean Drilling Program).

Cande, S.C., and Leslie, R.B., 1986. Late Cenozoic tectonics of the southern Chile Trench. J. Geophys. Res., 91:471-496.

Cande, S.C., Leslie, R.B., Parra, J.C., and Hobart, M., 1987. Interaction between the Chile Ridge and Chile Trench: geophysical and geothermal evidence. J. Geophys. Res., 92:495-520.

Clapperton, C.M., 1990. Quaternary glaciations in the Southern hemisphere: an overview. Quat. Sci. Rev., 9:299-304.

Cloos, M., 1993. Lithospheric buoyancy and collisional orogenesis: subduction of oceanic plateaus, continental margins, island arcs, spreading ridges, and seamounts. Geol. Soc. Am. Bull., 105:715-737.

DeLong, S.E., Fox, P.J., and McDowell, F.W., 1978, Subduction of the Kula Ridge at the Aleutian Trench. Geol. Soc. Am. Bull., 89:83-95.

DeLong, S.E., Schwarz, W.M., and Anderson, R.N., 1979. Thermal effects of ridge subduction. Earth Planet. Sci. Lett., 44:239-246.

Drewry, D.J., 1986. Glacial Geologic Processes: London (Edward Arnold).

Einsele, G., 1991. Submarine mass flow deposits and turbidites. In Einsele, G., Ricken, W., and Seilacher, A. (Eds.), Cycles and Events in Stratigraphy: Berlin (Springer-Verlag), 313-339.

Forsythe, R.D., and Nelson, E., 1985. Geological manifestations of ridge collision: evidence from the Golfo de Penas-Taitao Basin, southern Chile. Tectonics, 4:477-495.

Forsythe, R.D., Nelson, E.P., Carr, M.J., Kaeding, M.E., Herve, M., Mpodozis, C., Soffia, J.M., and Harambour, S., 1986. Pliocene near-trench magmatism in southern Chile: a possible manifestation of ridge collision. Geology, 14:23-27.

Forsythe, R., and Prior, D., 1992. Cenozoic continental geology of South America and its relations to the evolution of the Chile Triple Junction. In Behrmann, J.H., Lewis, S.D., Musgrave, R.J., et al., Proc. ODP, Init. Repts., 141: College Station, TX (Ocean Drilling Program), 23-31.

Haq, B.U., 1991. Sequence stratigraphy, sea-level change, and significance for the deep sea. In Macdonald, D.I.M. (Ed.), Sedimentation, Tectonics and Eustasy: Sea Level Changes at Active Margins. Spec. Publ. Int. Assoc. Sedimentol., 12:3-39.

Haq, B.U., Hardenbol, J., and Vail, P.R., 1987. Chronology of fluctuating sea levels since the Triassic. Science, 235:1156-1167.

\footnotetext{
Abbreviations for names of organizations and publications in ODP reference lists follow the style given in Chemical Abstracts Service Source Index (published by American Chemical Society).
}

1988. Mesozoic and Cenozoic chronostratigraphy and cycles of sea-level change. In Wilgus, C.K., Hastings, B.S., Kendall, C.G.St.C., Posamentier, H.W., Ross, C.A., and Van Wagoner, J.C. (Eds.), Sea-Level Changes-An Integrated Approach. Spec. Publ.-Soc. Econ. Paleontol. Mineral., 42:72-108.

Hibbard, J.P., and Karig. D.E., 1990. Structural and magmatic response to spreading ridge subduction: an example from southwest Japan. Tectonics, 9:207-230.

Hill, P.R., 1984. Sedimentary facies of the Nova Scotian upper and middle continental slope, offshore eastern Canada. Sedimentology, 31:293-309.

Honza, E., Miyazaki, T., and Lock, J., 1989. Subduction erosion and accretion in Salomon Sea region. Tectonophysics, 160:49-62.

Johnson, R.W., Jaques, A.L., Langmuir, C.H., Perfit, M.R., Staudigel, H., Dunkley, P.N., Chappell, B.W., Taylor, S.R., and Baekisapa, M., 1987. Ridge subduction and forearc volcanism: petrology and geochemistry of rocks dredged from the western Solomon arc and Woodlark basin. Circum.-Pac. Counc. Energy Miner. Resour., Earth Sci. Ser., 7:155-226.

Kennedy, D.S., and Anderson, J.B., 1989. Glacial-marine sedimentation and Quaternary glacial history of Marguerite Bay, Antarctic Peninsula. Quat. Res., 31:255-276.

Lash, G.G., 1985. Recognition of trench fill in orogenic flysch sequences. Geology: 13:867-870.

Macdonald, D.I.M. (Ed.), 1991. Sedimentation, Tectonics and Eustasy. Spec. Publ. Int. Assoc. Sedimentol., 12.

Marsaglia, K.M., and Ingersoll, R.V., 1992. A reassessment of magmatic-arc provenance: compositional trends in arc-related, deep-marine sand and sandstone. Geol. Soc. Am. Bull., 104:1637-1649.

Marshak, R.S., and Karig, D.E., 1977. Triple junctions as a cause for anomalously near-trench igneous activity between the trench and volcanic arc. Geology, 5:233-236.

Mercer, J.H., 1976. Glacial history of southernmost South America. Quat. Res., 6:125-166.

1983. Cenozoic glaciations in the Southern Hemisphere. Annu. Rev. Earth Planet. Sci., 11:99-132.

Moore, J., Byrne, T., Plumley, P., Reid, M., Gibbons, H., and Coe, R., 1983. Paleogene evolution of the Kodiak Island, Alaska: consequences of ridgetrench interactions in a more southerly latitude. Tectonics, 2:265-293.

Nur, A., and Ben-Avraham, Z., 1983. Volcanic gaps due to oblique consumption of aseismic ridges. Tectonophysics, 99:355-362.

Pickering, K., Stow, D., Watson, M., and Hiscott, R., 1986. Deep-water facies, processes and models: a review and classification scheme for modern and ancient sediments. Earth-Sci. Rev., 223:75-174.

Pickering, K.T., Hiscott, R., and Hein, F.J., 1989. Deep-marine Environments: Clastic Sedimentation and Tectonics: London (Unwin Hyman).

Piper, D.J.W., and Stow, D.A.V., 1991. Fine-grained turbidites, In Einsele, G., Ricken, W., and Seilacher, A. (Eds.), Cycles and Events in Stratigraphy: New York (Springer Verlag), 360-376.

Pope, P.G., and Anderson, J.B., 1992. Late Quaternary glacial history of the northern Antarctic Peninsula's western continental shelf: evidence from the marine record. Contr. Antarct. Res. III, Antarct. Res. Ser., 57:63-91.

Rabassa, J., and Clapperton, C.M., 1990. Quaternary glaciations of the southern Andes. Quat. Sci. Rev., 9:153-174.

Shanmugam, G., and Moiola, R.J., 1982. Eustatic control of turbidites and winnowed turbidites. Geology, 10:231-235.

1988. Submarine fans: characteristics, models, classification, and reservoir potential. Earth-Sci. Rev., 24:383-428.

Shanmugam, G., Spalding, T.D., and Rofheart, D.H., 1993. Traction structures in deep-marine, bottom-current-reworked sands in the Pliocene and Pleistocene, Gulf of Mexico. Geology, 21:929-932.

Shipboard Scientific Party, 1992a. Site 859. In Behrmann, J.H., Lewis, S.D., Musgrave, R.J., et al., Proc. ODP, Init. Repts., 141: College Station, TX (Ocean Drilling Program), 75-157.

, 1992b. Site 860. In Behrmann, J.H., Lewis, S.D., Musgrave, R.J., et al., Proc. ODP, Init. Repts., 141: College Station, TX (Ocean Drilling Program), 159-238.

, 1992c. Site 861. In Behrmann, J.H., Lewis, S.D., Musgrave, R.J., et al., Proc. ODP, Init. Repts., 141: College Station, TX (Ocean Drilling Program), 239-299.

-, 1992d. Site 862. In Behrmann, J.H., Lewis, S.D., Musgrave, R.J., et al., Proc. ODP, Init. Repts., 141: College Station, TX (Ocean Drilling Program), 301-341.

, 1992e. Site 863. In Behrmann, J.H., Lewis, S.D., Musgrave, R.J., et al., Proc. ODP, Init. Repts., 141: College Station, TX (Ocean Drilling Program), 343-446. 
Simkin, T., Siebert, L., McChelland, L., Bridge, D., Newhall, C., and Latter, J.H., 1981. Volcanoes of the World: Stroudsburg, PA (Hutchinson \& Ross).

Sisson, V.B., and Pavlis, T.L., 1993. Geologic consequences of plate reorganization: an example from the Eocene southern Alaska fore arc. Geology, 21:913-916.

Stow, D.A.V.(Ed.), 1992. Deep-Water Turbidite Systems. Int. Assoc. Sedimentol., Preprint Ser., 3.

Stow, D.A.V., and Lovell, J.P.B., 1979. Contourites: their recognition in modern and ancient sediments. Earth-Sci. Rev., 14:251-291.

Stow, D.A.V., and Shanmugam, G., 1980. Sequences of structures in finegrained turbidites: comparison of recent deep-sea and ancient flysch sediments. Sediment. Geol., 25:23-42.

Thorkelson, D.J., and Taylor, R.P., 1989. Cordilleran slab windows. Geology, 17:833-836.

Thornburg, T.M., and Kulm, L.D., 1987. Sedimentation in the Chile Trench: depositional morphologies, lithofacies, and stratigraphy. Geol. Soc. Am. Bull., 98:33-52.

Thornburg, T.M., Kulm, L.D., and Hussong, D.M., 1990. Submarine-fan development in the southern Chile Trench: a dynamic interplay of tectonics and sedimentation. Geol. Soc. Am. Bull., 102:1658-1650.

Tucholke, B.E., Hollister, C.D., Weaver, F.M., and Vennum, W.R., 1976. Continental rise and abyssal plain sedimentation in the southeast Pacific basin-
Leg 35 Deep Sea Drilling Project. In Hollister, C.D., Craddock, C., et al., Init. Repts. DSDP, 35: Washington (U.S. Govt. Printing Office), 359-400.

Underwood, M.B., and Bachman, S.G.. 1982. Sedimentary facies associations within subduction complexes. In Leggett, J.K. (Ed.), Trench-Forearc Geology: Sedimentation and Tectonics on Modern and Ancient Active Plate Margins. Geol. Soc. Spec. Publ. London, 10:537-550.

von Huene, R., and Lallemand, S., 1990. Tectonic erosion along the Japan and Peru convergent margins. Geol. Soc. Am. Bull., 102:704-720.

Weissel, J.K., Taylor, B., and Karner, G.D., 1982. The opening of the Woodlark basin, subduction of the Woodlark spreading system, and the evolution of northern Melanesia since mid-Pliocene time. Tectonophysics, 87:253-277.

Wright, R., and Anderson, J.B., 1982. The importance of sediment gravity flow to sediment transport and sorting in a glacial marine environment: Weddell Sea, Antarctica. Geol. Soc. Am. Bull., 93:951-963.

Date of initial receipt: 21 March 1994

Date of acceptance: 29 .July 1994

Ms 141SR-037 